\title{
Design and Synthesis of Non-peptide RGD Mimics for Evaluation of Their Utility as Anti-platelet Agents
}

\author{
Kazuhiro Higuchi,* Hideki Hikita, Asumi Murayama, Daichi Yuri, Natsu Kobayakawa, \\ Takashi Takahashi, Shigeru Kojima, Hiroko Ueno, Tomomi Hatakeyama, Airi Kato, \\ Masanori Tayu, Etsuko Oyama, Shigeo Sugiyama, Kazuyuki Ishii, Hidenobu Takahashi, and \\ Tomomi Kawasaki*
}

Meiji Pharmaceutical University; 2-522-1 Noshio, Kiyose, Tokyo 204-8588, Japan.

Received July 23, 2016; accepted September 19, 2016

Arg-Gly-Asp (RGD) mimics were synthesized and their anti-platelet activity was evaluated. A concise method was developed for the synthesis of the target compounds from dehydroepiandrosterone and WielandMiescher and Hajos-Parrish ketones, which are suitable for readily available platform. Among the synthesized compounds, the perhydronaphthalene framework with a 3-(4-piperidinyl)propoxyl structure 3e possessed the highest anti-aggregative activity. $\mathrm{The}^{\mathrm{IC}} \mathrm{C}_{50}$ values of $3 \mathrm{e}$ were $0.91 \mathrm{~mm}$ (ADP initiation) and $0.54 \mathrm{~mm}$ (collagen initiation).

Key words non-peptide Arg-Gly-Asp (RGD) mimic; antiplatelet agent; dehydroepiandrosterone; WielandMiescher ketone; Hajos-Parrish ketone

Platelets play an important role in hemostasis; however, its aggregation triggers several serious diseases, including cardiovascular, cerebrovascular, and peripheral vascular diseases. Platelet aggregation process is occurred by the stimulation of various physiological activators such as ADP, collagen and thrombin. ${ }^{1,2)}$ Finally the stimulation derives the structural transformation of glycoprotein $\mathrm{IIb} / \mathrm{IIIa}$ (integrin $\alpha \mathrm{IIb} \beta 3$ ) on the platelet surface. The activated GPIIb/IIIa receptor interacts with fibrinogen to induce platelet aggregation. ${ }^{3-5)}$ The interaction between GPIIb/IIIa and fibrinogen is mediated by the Arg-Gly-Asp (RGD) sequence in fibrinogen. ${ }^{6-8)}$ Additionally, the $\beta$-turn structure formed by the sequence enhances the interaction of each molecules. ${ }^{9}{ }^{10}$ ) Therefore, RGD mimics are valuable platelet aggregation antagonists, and many compounds have been developed. ${ }^{11-14)}$ Among them, tirofiban (1) ${ }^{15)}$ and eptifibatide (2), ${ }^{16)}$ were launched for clinical use (Fig. 1).

To develop a more efficient approach to RGD mimics, we assumed that the shape and volume of the $\beta$-turn structure is equal to that of perhydro polycyclic hydrocarbon structures such as perhydro-phenanthrene, ${ }^{17,18)}$-naphthalene, and -indene (Fig. 2). Therefore, these hydrocarbons, with acidic and basic moieties of the appropriate position and size, were hypothesized to be good candidate for antiplatelet agents. Moreover, such compounds should be biologically stable and show better oral bioavailability than the peptide ligands. Additionally, a method for stereoselective transformation of such compounds is available, based on established concepts in steroid chemistry, enabling detailed conformational analysis of the ligand docking site. We planned to develop a method for synthesis of the orally active antiplatelet agents $\mathbf{3 a}-\mathbf{e}$ from the readily available dehydroepiandrosterone (4) and Wieland-Miescher (5) and Hajos-Parrish ketones (6). Herein, we report the synthesis of the target peptide mimic compounds and an evaluation of those antiplatelet activities.

\section{Chemistry}

First, for preparation of the perhydrophenanthrene compounds $\mathbf{3 a}$ and $\mathbf{b}$, the common intermediate $\mathbf{1 1}$ was synthesized from dehydroepiandrosterone 4 (Chart 1). Acetalization of the ketone $4^{19)}$ and Oppenauer oxidation of the secondary alcohol accompanying isomerization of the olefin yielded an enone. $^{20)}$ The stereoselective 1,4-reduction of the enone under Birch conditions ${ }^{21)}$ quenching with solid $\mathrm{NH}_{4} \mathrm{Cl}$ afforded $7,{ }^{22)}$ and then Horner-Wadsworth-Emmons olefination provided the $\alpha, \beta$-unsaturated ester 8a. One-electron reduction of the $\alpha, \beta$-unsaturated ester in $\mathbf{8 a}$ with magnesium metal ${ }^{23)}$ gave a mixture of stereoisomers $(\beta: \alpha=1: 1)$; however, Birch reduction of $\alpha, \beta$-unsaturated carboxylic acid $\mathbf{8} \mathbf{b}^{24)}$ gave the $\beta$-rich isomer 9 with excellent selectivity $(\beta: \alpha=>10: 1)$. Methylation of carboxylic acid $\mathbf{9 b}$ and deacetalization of $\mathbf{9 a}$ afforded compound

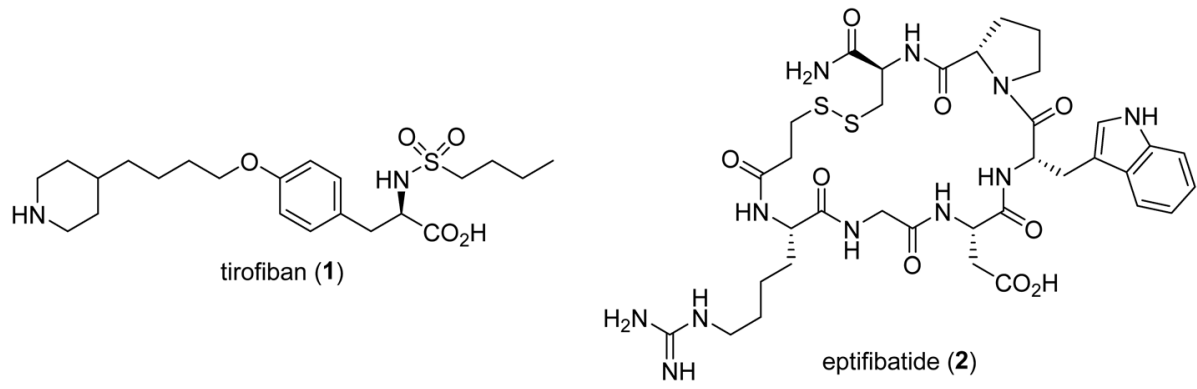

Fig. 1. RGD Mimics for Acute Platelet Diseases 


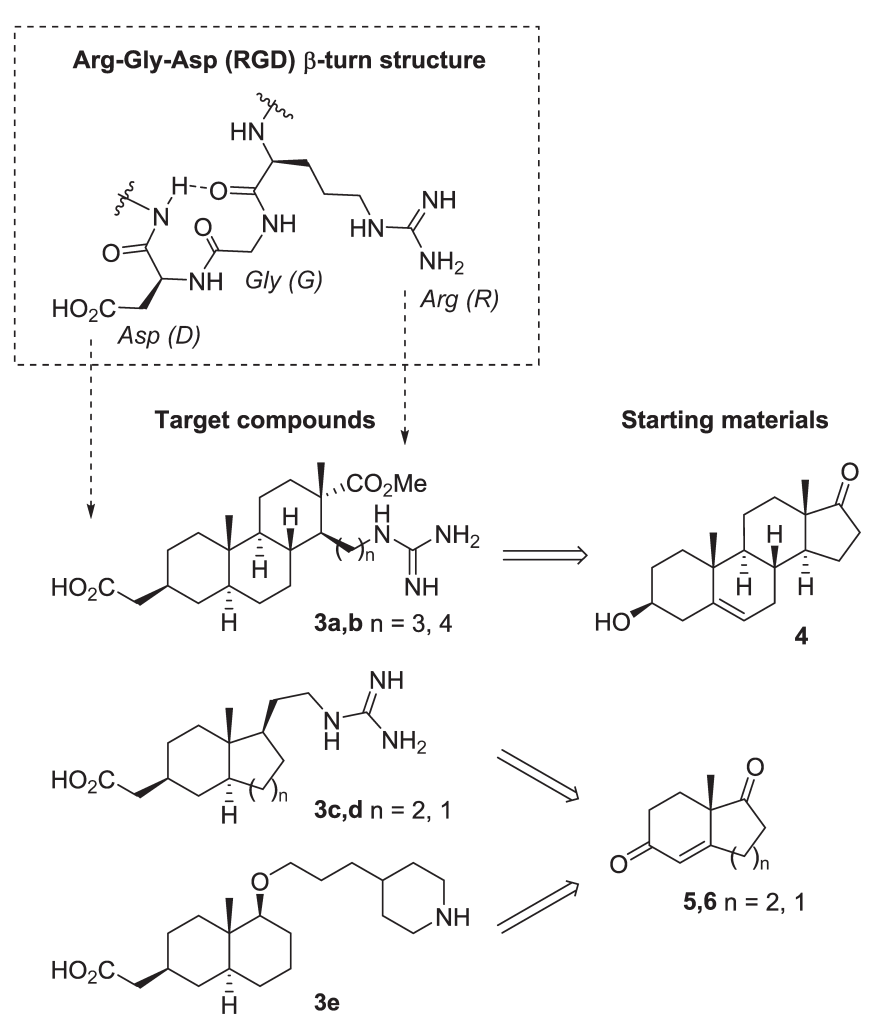

Fig. 2. Synthetic Strategy for RGD Mimics 3a-e
10, which was converted to the intermediate $\mathbf{1 1}$ by ozonolysis of the enol acetate of $\mathbf{1 0}$, followed by methylation of the carboxylic acid provided. ${ }^{25,26)}$

Side-chain elongation of intermediate $\mathbf{1 1}$ was carried out by Horner-Wadsworth-Emmons (HWE) olefination with diethyl cyanomethyl phosphonate to yield 12 (Chart 2). Hydrogenation of the $\alpha, \beta$-unsaturated nitrile in $\mathbf{1 2}$ with Adams' catalyst ${ }^{27,28)}$ followed by tert-butoxycarbonyl (Boc) protection afforded the carbamate 13. Hydrolysis of the primary ester and subsequent deprotection afforded a primary amine. Finally, the guanidine formation from the amine with $N, N^{\prime}$-bis(Boc)-1 $H$-pyrazole-1carboxamidine and subsequent deprotection ${ }^{29)}$ gave the target compound 3a.

An alternative target compound, $\mathbf{3 b}$, which is one carbon shorter at the side chain than compound $\mathbf{3 a}$, was synthesized from intermediate 11, by the following procedure (Chart 3).

Wittig chain elongation of intermediate 11, using methoxymethyl triphenylphosphonium chloride followed by hydrolysis of the enolate, produced aldehyde 14. Condensation between aldehyde $\mathbf{1 4}$ and hydroxylamine, ${ }^{30)}$ followed by hydrogenation $^{31)}$ and protection of the amine produced compound $\mathbf{1 5}$, at $78 \%$ yield. The following transformation to the target compound $\mathbf{3 b}$ was achieved by the same procedure as the synthesis of compound 3a.

For regulation of the hydrophilicity of the test compounds, we synthesized bicyclic compounds such as perhydro-naphthalene and -indene from Wieland-Miescher (5) and Hajos-Par-

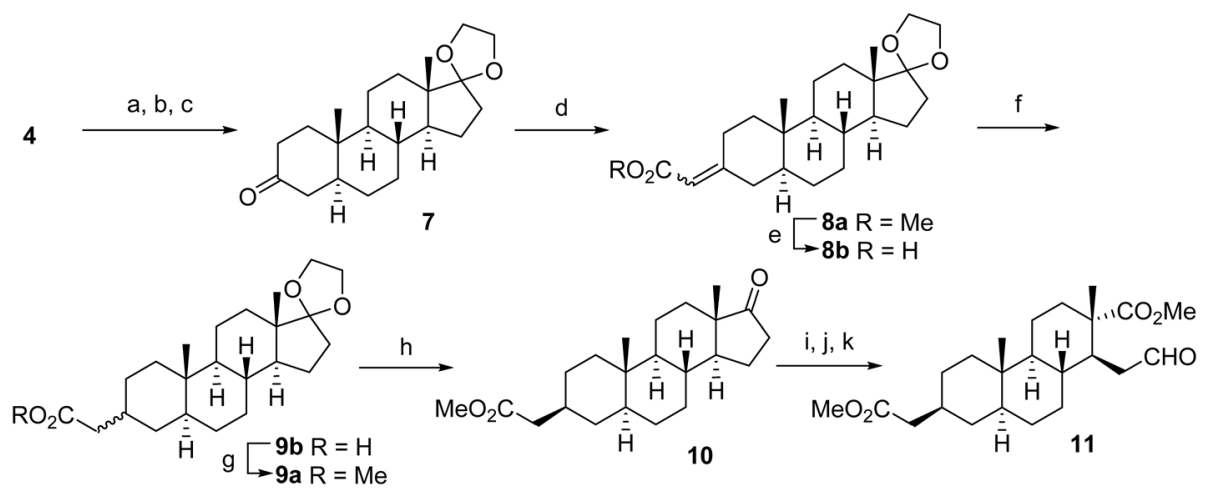

Reagents and conditions: (a) $\left(\mathrm{CH}_{2} \mathrm{OH}\right)_{2}, \mathrm{CSA}$, benzene, reflux, $80 \%$; (b) $\mathrm{Al}\left(\mathrm{OPr}^{i}\right)_{3}$, cyclohexanone, toluene, reflux, $97 \%$; (c) $\mathrm{Li}, 1$ liq. $\mathrm{NH}$, $\mathrm{THF},-78^{\circ} \mathrm{C}$, then $\mathrm{NH} \mathrm{Cl}_{4} \mathrm{Cl}, 88 \%$; (d) $(\mathrm{EtO})_{2} \mathrm{P}(\mathrm{O}) \mathrm{CH}_{2} \mathrm{CO}_{2} \mathrm{Me}, \mathrm{KOBu}^{t}, \mathrm{DMF}, 0^{\circ} \mathrm{C}$-r.t., $97 \%$; (e) $\mathrm{KOH}, \mathrm{EtOH} / \mathrm{H}_{2} \mathrm{O}, 90^{\circ} \mathrm{C}$; (f) $\mathrm{Li}, \mathrm{liq}^{\circ} \mathrm{NH}_{3},{ }^{t} \mathrm{BuOH}, \mathrm{THF} / \mathrm{dioxane},-78^{\circ} \mathrm{C}, \beta: \alpha=>10: 1 ;(\mathrm{g}) \mathrm{MeI}, \mathrm{NaH}, \mathrm{DMF}, \mathrm{r} . \mathrm{t}$; (h) $1.5 \mathrm{M} \mathrm{HCl}$, THF, r.t., $91 \%$ in 4 steps; (i) isopropenyl acetate, conc. $\mathrm{H}_{2} \mathrm{SO}_{4}$, reflux, $75 \%$; (j) $\mathrm{O}_{3}, \mathrm{CH}_{2} \mathrm{Cl}_{2} / \mathrm{AcOH}$, then $\mathrm{Me}_{2} \mathrm{~S}, \mathrm{AcOH} \mathrm{H}_{2} \mathrm{O},-78^{\circ} \mathrm{C}$ to r.t.; $(\mathrm{k}) \mathrm{CH}_{2} \mathrm{~N}_{2}, \mathrm{Et}_{2} \mathrm{O}$, $0^{\circ} \mathrm{C}, 83 \%$ in 2 steps.

Chart 1
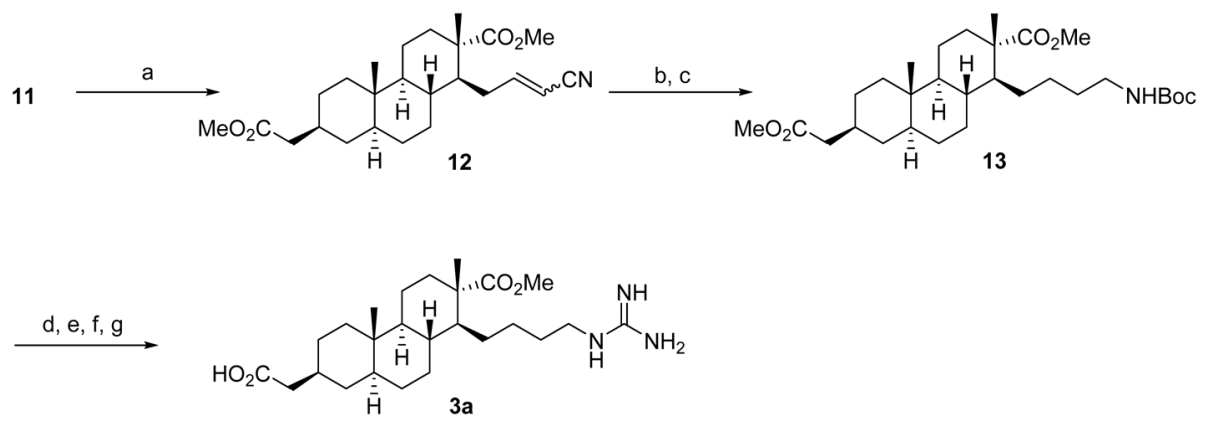

Reagents and conditions: (a) (EtO) $)_{2} \mathrm{P}(\mathrm{O}) \mathrm{CH}_{2} \mathrm{CN}, \mathrm{KOBu}^{t}, \mathrm{DMF}, 0^{\circ} \mathrm{C}$ to r.t., $96 \%$; (b) $\mathrm{PtO}_{2}, \mathrm{H}_{2}, \mathrm{HCl} / \mathrm{MeOH} \mathrm{CHCl}_{3}$, r.t.; (c) $\mathrm{Boc}_{2} \mathrm{O}$, $\mathrm{Et}_{3} \mathrm{~N}$, $\mathrm{CH}_{2} \mathrm{Cl}_{2}$, $0{ }^{\circ} \mathrm{C}$ to r.t., $95 \%$ in 2 steps; (d) $10 \% \mathrm{LiOH}$ aq., $\mathrm{Bu}_{4} \mathrm{NHSO}_{4}, \mathrm{MeOH} / \mathrm{THF}, 0^{\circ} \mathrm{C}$ to r.t., quant.; (e) TFA, $\mathrm{CH}_{2} \mathrm{Cl}_{2}, 0^{\circ} \mathrm{C}$ to r.t.; (f) $N, N^{\prime}$-bis (tert-butoxycarbonyl)-1H-pyrazole-1-carboxamidine, pyridine, $0^{\circ} \mathrm{C}$ to r.t., quant. in 2 steps; $(\mathrm{g}) \mathrm{TFA}, \mathrm{CH}_{2} \mathrm{Cl}_{2}, 0^{\circ} \mathrm{C}$ to r.t., $87 \%$. 
rish ketones (6) (Charts 4, 5).

At first, a keto-acetal $\mathbf{1 7}$ was produced from 5, via a previously reported procedure ${ }^{32-34)}$ (Chart 4). To introduce the carboxyl unit, a HWE reaction of 17 yielded the $\alpha, \beta$ unsaturated ester 18a at $93 \%$ yield, as a mixture of geo- metric isomers $(E: Z=1: 1)$. Hydrogenation or one-electron reduction of 18 a with magnesium metal afforded a mixture of epimers $(\beta: \alpha=1: 1$ to $8: 1)$. In contrast, the Birch reduction of carboxylic acid $\mathbf{1 8 b}$ followed by deacetalization and esterification gave the desired $\beta$ compound 19 in good yield.

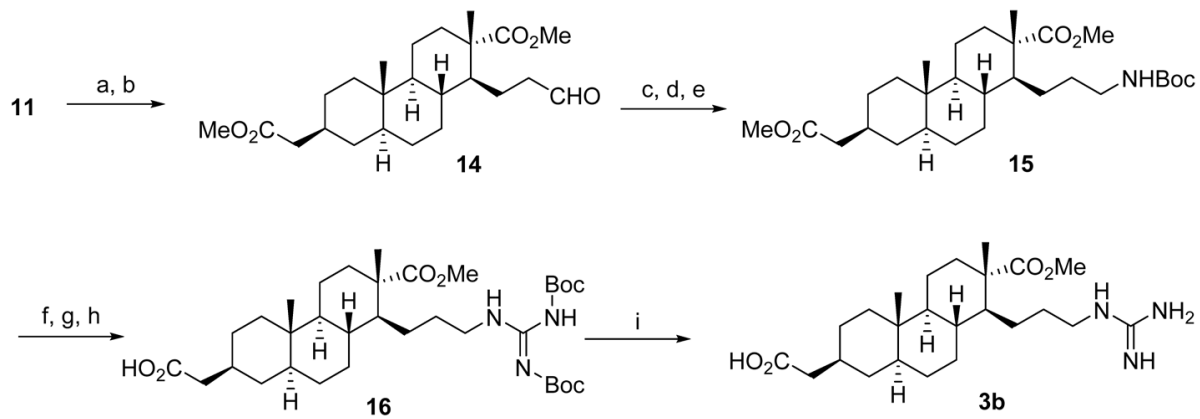

Reagents and conditions: (a) $\mathrm{MeOCH}_{2} \mathrm{PPh}_{3} \cdot \mathrm{Cl}$, LHMDS, THF, $-78^{\circ} \mathrm{C}, 4 \mathrm{~h}, 73 \%$; (b) $p$ - $\mathrm{TsOH} \cdot \mathrm{H}_{2} \mathrm{O}$, acetone $/ \mathrm{H}_{2} \mathrm{O} ; 0{ }^{\circ} \mathrm{C}$ to r.t., $73 \%$; (c) $\mathrm{NH} \mathrm{OH}_{2} \cdot \mathrm{HCl}$, Et ${ }_{3} \mathrm{~N}$, EtOH, r.t.; $(\mathrm{d})$ $\mathrm{PtO}_{2}, \mathrm{H}_{2}$, AcOH, r.t.; (e) $\mathrm{Boc}_{2} \mathrm{O}, \mathrm{Et}_{3} \mathrm{~N}, \mathrm{CH}_{2} \mathrm{Cl}_{2}, 0^{\circ} \mathrm{C}$ to r.t., $78 \%$ in 3 steps; (f) $10 \% \mathrm{LiOH}$ aq., $\mathrm{Bu}_{4} \mathrm{NHSO}_{4}$, $\mathrm{MeOH}^{\mathrm{THHF}}, 0^{\circ} \mathrm{C}$ to r.t., quant.; (g) TFA, $\mathrm{CH}{ }_{2} \mathrm{Cl}{ }_{2}$, $0^{\circ} \mathrm{C}$ to r.t.; (h) $N, N^{\prime}$-bis(tert-butoxycarbonyl)- $1 \mathrm{H}$-pyrazole-1-carboxamidine, pyridine, $0^{\circ} \mathrm{C}$ to r.t., $71 \%$ in 2 steps; (i) $\mathrm{TFA}, \mathrm{CH}_{2} \mathrm{Cl}_{2}, 0^{\circ} \mathrm{C}$ to r.t., quant

Chart 3
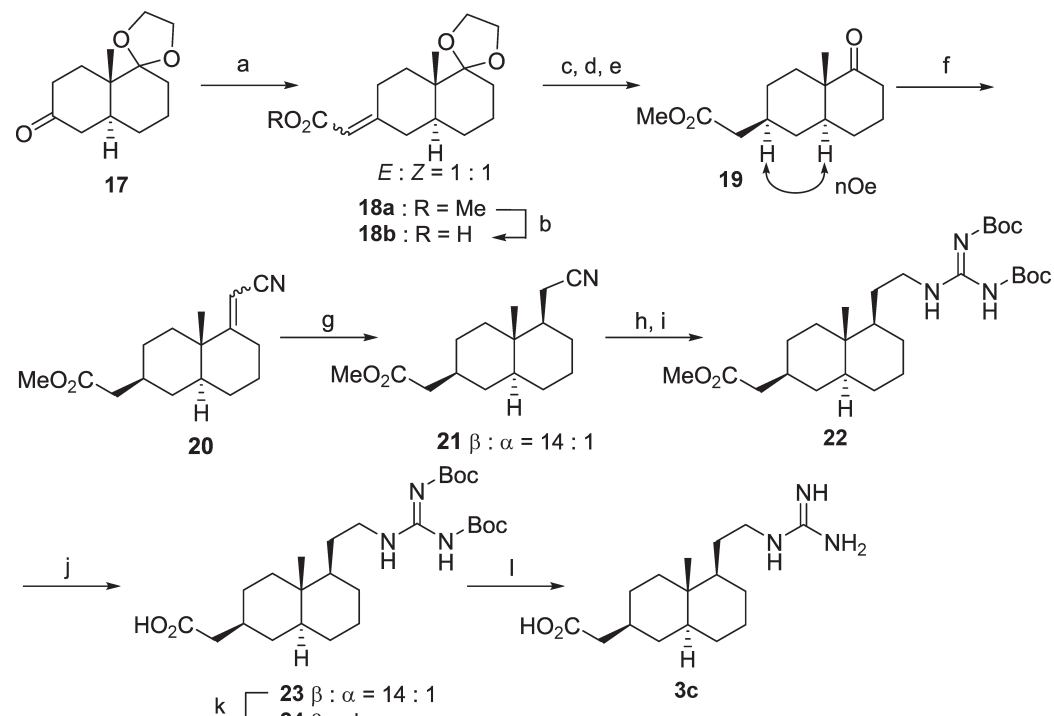

Reagents and conditions: (a) (EtO) $)_{2} \mathrm{P}(\mathrm{O}) \mathrm{CH}_{2} \mathrm{CO}_{2} \mathrm{Me}, \mathrm{KOBu}^{t}$, DMF, r.t., $98 \%$; (b) $\mathrm{KOH}, \mathrm{EtOH} / \mathrm{H}_{2} \mathrm{O}, 90^{\circ} \mathrm{C}, 93 \%$; (c) $\mathrm{Li}$, liq. $\mathrm{NH}$, $\mathrm{THF},-78^{\circ} \mathrm{C}$; (d) $1.5 \mathrm{M} \mathrm{HCl}, \mathrm{THF}, \mathrm{r.t}$; (e) MeI, $\mathrm{K}_{2} \mathrm{CO}_{3}$, acetone, r.t., $91 \%$ in 3 steps; (f) $(\mathrm{EtO}){ }_{2} \mathrm{P}(\mathrm{O}) \mathrm{CH}_{2} \mathrm{CN}, \mathrm{KOBu}^{t}, \mathrm{DMF}, 70^{\circ} \mathrm{C}, 95 \%$; (g) $10 \% \mathrm{Pd} / \mathrm{C}, \mathrm{H}_{2}, \mathrm{EtOH}, 1.5 \mathrm{~h}, \mathrm{quant}$. $(\beta: \alpha=14: 1)$; (h) $\mathrm{PtO}$, $\mathrm{H}_{2}, 10 \% \mathrm{HCl}-$ $\mathrm{MeOH}$, r.t.; (i) $N, N^{\prime}$-bis(tert-butoxycarbonyl)- $1 \mathrm{H}$-pyrazole-1-carboxamidine, Et ${ }_{3} \mathrm{~N}$, DMF, r.t., $83 \%$ in 2 steps; (j) $10 \% \mathrm{LiOH}$ aq., $\mathrm{MeOH}-\mathrm{THF}$, $0^{\circ} \mathrm{C}$ to r.t., $75 \%$; (k) recrystallization $13 \%$; (1) $4 \mathrm{~m} \mathrm{HCl}-\mathrm{AcOEt}, 0^{\circ} \mathrm{C}$ to r.t., quant.

Chart 4

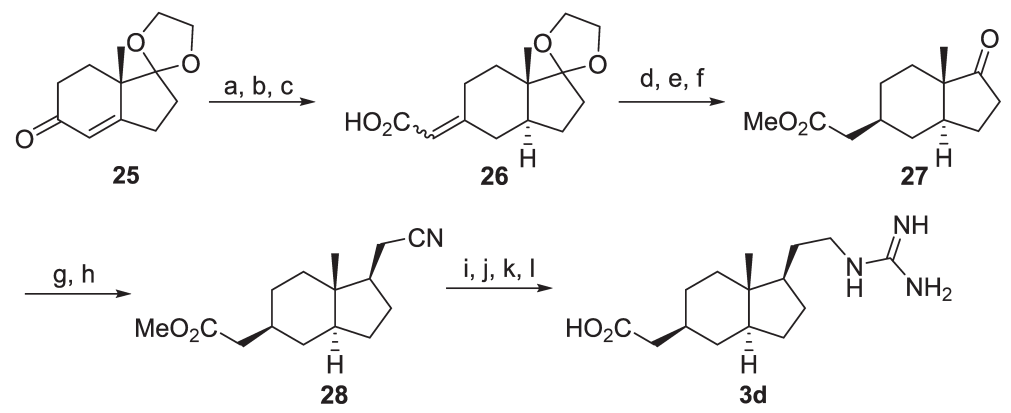

Reagents and conditions: (a) Li, liq. $\mathrm{NH}_{3}, \mathrm{THF},-78^{\circ} \mathrm{C}$, then $\mathrm{NH}_{4} \mathrm{Cl}, 70 \%$; (b) $(\mathrm{EtO}){ }_{2} \mathrm{P}(\mathrm{O}) \mathrm{CH}_{2} \mathrm{CO}_{2} \mathrm{Me}, \mathrm{KOBu}$, $\mathrm{DMF}$, r.t., $97 \%$; (c) $\mathrm{KOH}$, EtOH/ $\mathrm{H}_{2} \mathrm{O}$, r.t., $71 \%$; (d) $\mathrm{Li}$, liq. $\mathrm{NH}_{3}$, THF, $-78^{\circ} \mathrm{C}$, then $\mathrm{NH}_{4} \mathrm{Cl}$; (e) $1.5 \mathrm{M} \mathrm{HCl}$, THF, r.t.; (f) $\mathrm{MeI}, \mathrm{K}_{2} \mathrm{CO}_{3}$, acetone, r.t., $98 \%$ in 3 steps; (g) $(\mathrm{EtO}) 2 \mathrm{P}(\mathrm{O}) \mathrm{CH}{ }_{2} \mathrm{CN}, \mathrm{NaH}$, DMF, r.t., $93 \%$; (h) $10 \% \mathrm{Pd} / \mathrm{C}$, $\mathrm{H}_{2}$, EtOH, r.t., $80 \%$; (i) $\mathrm{PtO}_{2}, \mathrm{H}_{2}, 10 \% \mathrm{HCl}-\mathrm{MeOH}$; (j) $N, N^{\prime}$-bis(tert-butoxycarbonyl)- $1 \mathrm{H}$-pyrazole-1-carboxamidine, Et ${ }_{3} \mathrm{~N}$, DMF, r.t., $13 \%$ in 2 steps; (k) $10 \%$ LiOH aq., $\mathrm{MeOH}-\mathrm{THF}$, r.t., $82 \%$; (1) $4 \mathrm{M} \mathrm{HCl}-\mathrm{AcOEt}$, r.t., $56 \%$. 

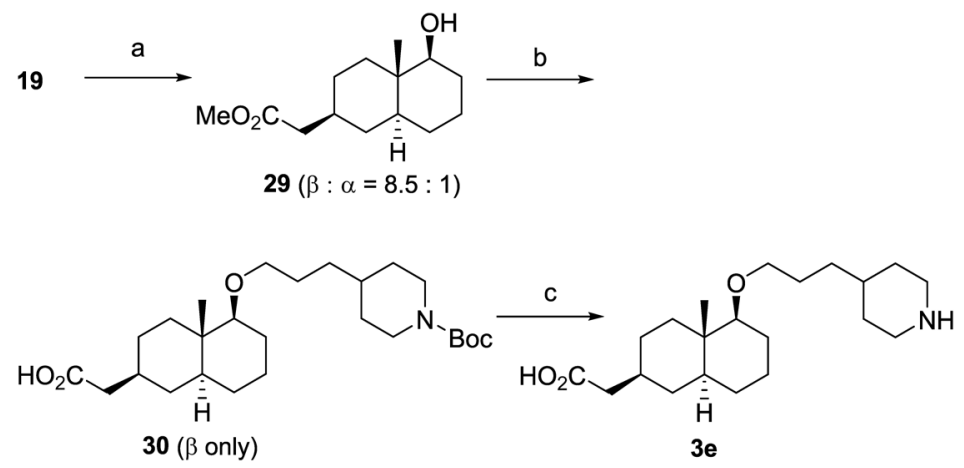

Reagents and conditions: (a) $\mathrm{NaBH}_{4}, \mathrm{MeOH}^{\circ}{ }^{\circ} \mathrm{C}, 83 \%$; (b) tert-butyl 4-(3-bromopropyl)piperidine-1-carboxylate, $\mathrm{NaH}, \mathrm{DMF}$, r.t., $29 \%$; (c) 4m $\mathrm{HCl}-\mathrm{AcOEt}$, r.t., $75 \%$.

Chart 6

Side-chain elongation with diethyl cyanomethylphosphonate and potassium tert-butoxide gave $\mathbf{2 0}$ at $95 \%$ yield. The direct transformation of the cyanomethylidene moiety in $\mathbf{2 0}$ to an aminoethyl group, using Adams' catalyst, resulted in a mixture of diastereomers $(\beta: \alpha=1: 1)$. Stepwise transformation by hydrogenation of the olefin in $\mathbf{2 0}$ with $10 \%$ palladium on carbon ( $\beta: \alpha=14: 1$, determined the by ${ }^{1} \mathrm{H}-\mathrm{NMR}$ spectrum) and hydrogenation of the cyano group in $\mathbf{2 1}$ with Adams' catalyst followed by amidylation of the amine gave the guanidino compound $\mathbf{2 2}$ at good yield and diastereoselectivity. After hydrolysis of the ester 22 with $10 \% \mathrm{LiOH}$ aq., the carboxylic acid was recrystallized to give the diastereomerically pure $\beta$-compound 24. Finally, deprotection of the $N$-Boc guanidino compound 24 using $4 \mathrm{M} \mathrm{HCl}$ yielded the target compound $\mathbf{3 c}$.

The indene core compound $\mathbf{3 d}$ was also synthesized from a Hajos-Parrish ketone (6), ${ }^{35,36)}$ following the same procedure as described for compound 3c (Chart 5).

We also synthesized a pyrrolidino compound, $\mathbf{3 e}$, from the intermediate 19 (Chart 6). The reduction of ketone 19, which was synthesized in Chart 4, with $\mathrm{NaBH}_{4}$ afforded the alcohol $29\left(\beta: \alpha=8.5: 1\right.$, determined by the ${ }^{1} \mathrm{H}-\mathrm{NMR}$ spectrum). Etherification of the secondary alcohol in 29 with $N$-Boc bromopropyl piperidine ${ }^{37)}$ gave compound 30. Finally, deprotection of the $N$-Boc guanidino compound $\mathbf{3 0}$, using $4 \mathrm{M} \mathrm{HCl}$, afforded the target compound $\mathbf{3 e}$.

Thus, accessibility to test compounds such as $\mathbf{3 e}$ will facilitate evolution of the structural diversity of RGD mimic analogs.

\section{Biological Activity}

In a preliminary study, the tricyclic compounds $\mathbf{3 a}$ and $\mathbf{b}$ were only slightly soluble in a buffer solution and dimethyl sulfoxide (DMSO), preventing testing of their anti-platelet activity. Therefore, we investigated the anti-platelet activity of the soluble bicyclic compounds $\mathbf{3 c}-\mathbf{e}$, which have low-lipophilicity cores relative to $\mathbf{3 a}$ and $\mathbf{b}$. Initially, the dependence of the anti-platelet activity of compound $\mathbf{3 c}$ on concentration was measured by initiation with both ADP (Fig. 3, left) and collagen (Fig. 3, right) in platelet-rich plasma (PRP). The extent of platelet aggregation was measured at 5 min after addition of ADP. Maximum aggregation of the control was set as $100 \%$. A strong correlation was observed between the concentration and the antiplatelet activity of $\mathbf{3 c}$, using each inducer.

Next, the anti-aggregative activity of compounds $\mathbf{3 c}-\mathbf{e}$ was investigated in ADP-induced platelet aggregation (Fig. 4). The aggregation ratio of the perhydronaphthalene $\mathbf{3 c}$ was much higher than that of the perhydroindane 3d (Fig. 4, left). Comparison of the activities of the perhydronaphthalenes $3 \mathbf{c}$ and $\mathbf{e}$ indicated that the 3-(4-piperidinyl)propoxyl moiety in $\mathbf{3 e}$ is more effective than the guanidino group in $\mathbf{3 c}$. In addition, Arg-Gly-Asp-Ser (RGDS) showed extremely smooth and strong anti-platelet activity compared to $\mathbf{3 e}$ (Fig. 4, right). Antiplatelet activity of RGD mimics were evaluated from maximum aggregation value of each compound against that of control (Fig. 5). The maximum anti-aggregation ratio of 3e $(60 \%)$ was much higher than those of compounds $3 \mathbf{c}(41 \%)$ and $\mathbf{d}(17 \%)$.

\section{Conclusion}

We have studied the synthesis of RGD-mimic compounds and evaluated the anti-platelet activity of each compound. We have developed a concise method for synthesis of RGD mimics from readily available steroid and bicyclic ketones. Among the compounds synthesized, the perhydronaphthalene framework with the 3-(4-piperidinyl)propoxyl structure 3e possessed the highest anti-aggregative activity. Further analogue syntheses and those biological evaluation are under investigation.

\section{Experimental}

General Methods All melting points were measured on a Yanagimoto micro melting point apparatus and are uncorrected. Optical rotations were obtained using a JASCO P-2200 polarimeter. Optical purities were determined on a JASCO HPLC (PU-2089 plus, MD-2015 plus) instrument equipped with Daicel Chemical chiral columns. IR spectra were recorded on a Shimadzu IRPrestige-21 spectrophotometer. ${ }^{1} \mathrm{H}$ - and ${ }^{13} \mathrm{C}-\mathrm{NMR}$ spectra were measured on a JEOL JNM-AL300 (300 MHz), JEOL JMN-AL400 (400 MHz), JEOL JNM-LA500 $(500 \mathrm{MHz})$ or JNM-ECA500 $(500 \mathrm{MHz})$ spectrometers with tetramethylsilane as an internal standard. $J$-Values are given in Hertz. Mass spectra were recorded on a JEOL JMS-DX302 or JEOL JMS 700 instruments with a direct inlet system. Elemental analysis was performed using a Yanaco MT-6 elemental analyzer. Column chromatography was carried out on silica gel [Kanto Chemical Co., Inc., Japan (Silica Gel 60N, Spherical, neutral 40-50 $\mu \mathrm{m}$ ) and Merck Ltd. (Silica Gel $60 \mathrm{~F}_{254}, 230-400$ mesh)]. TLC was carried out on silica gel plates [Merck Ltd., Germany (TLC Silica gel $\left.60 \mathrm{~F}_{254}\right)$ ] and visualized with UV254 light and/or staining with phosphomolybdic acid in EtOH. The purity of compounds 3a-e were measured by the internal standard method using 1,4-bis(trimethylsilyl)benzene. ${ }^{38)}$ 

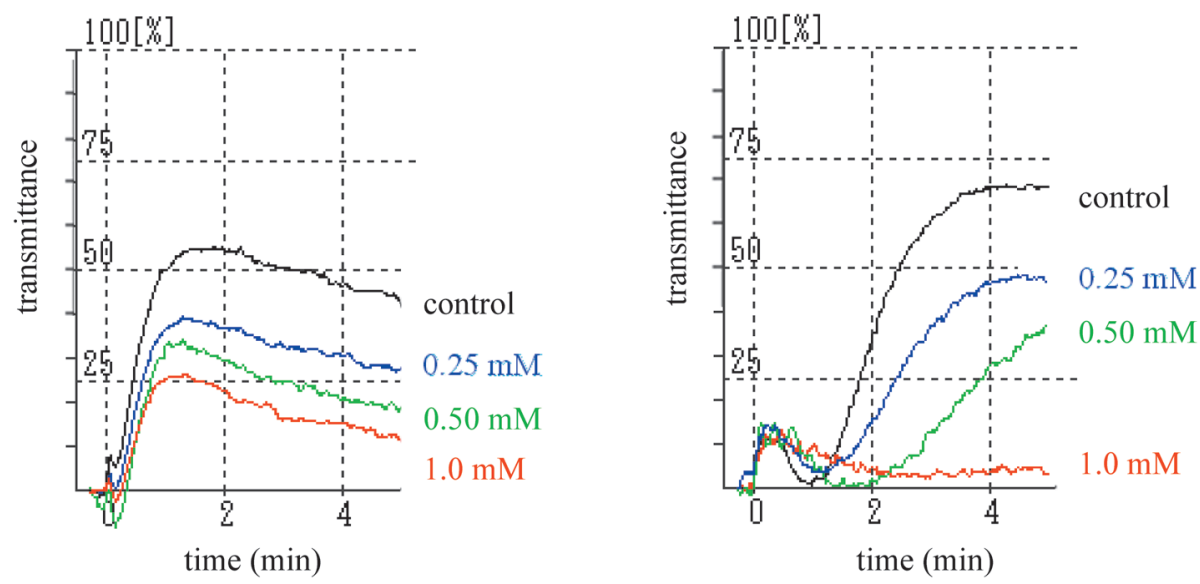

Fig. 3. Concentration Dependence of Platelet Aggregation by Compound 3c, Initiated by ADP (Left) and Collagen (Right)
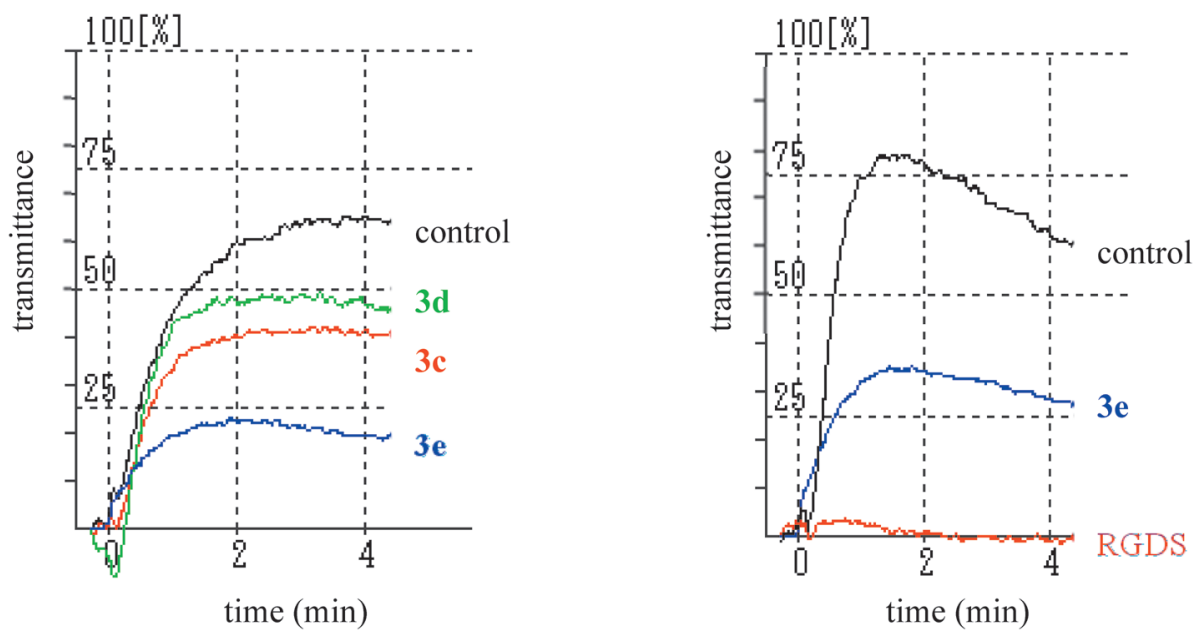

Fig. 4. Anti-platelet Activity of Compounds $\mathbf{3 c}-\mathbf{e}$ and RGDS (1.0 mm) on ADP-Induced Platelet Aggregation

Anti-platelet activities were monitored during $5 \mathrm{~min}$ after addition of an inducer.

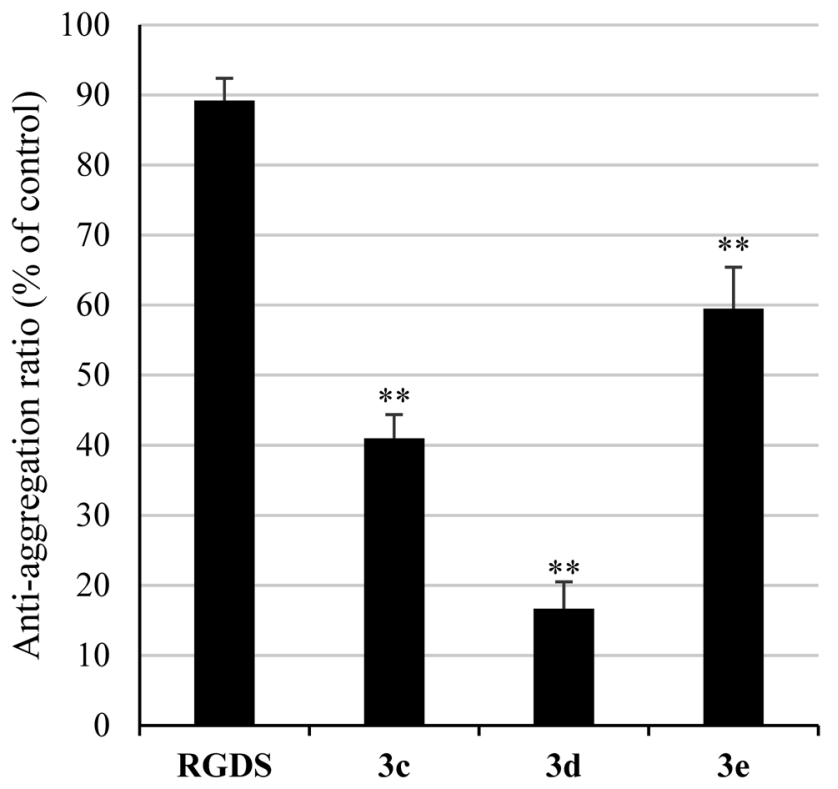

Fig. 5. Anti-platelet Activity of Compounds $\mathbf{3 c}-\mathbf{e}$ and RGDS (1.0 mm) on ADP-Induced Platelet Aggregation

Data are expressed as the mean \pm standard error (S.E.) $(n=6$ for $\mathbf{3 c}-\mathbf{e}, n=5$ for RGDS). ${ }^{* *} p<0.01$ compared with RGDS.
$(3 S, 8 R, 9 S, 10 R, 13 S, 14 S)$-10,13-Dimethyl-1,2,3,4,7,8,9, $10,11,12,13,14,15,16$-tetradecahydrospiro[cyclopenta[a]phenanthrene-17,2'-[1,3]dioxolan]-3-ol To a solution of 4 $(25.0 \mathrm{~g}, 86.7 \mathrm{mmol})$ in benzene $(420 \mathrm{~mL})$ were added ethylene glycol $(14.5 \mathrm{~mL}, \mathrm{~d} 1.11,259 \mathrm{mmol})$ and camphorsulfonic acid $(4.0 \mathrm{~g}, 17.2 \mathrm{mmol})$. The reaction mixture was heated under reflux using Dean-Stark apparatus for $3 \mathrm{~h}$. The mixture was cooled to room temperature (r.t.) and neutralized using satd aqueous $\mathrm{NaHCO}_{3}$ on an ice cooling bath. The mixture was extracted with EtOAc and the combined organic layer was washed with brine. The extract was dried over $\mathrm{MgSO}_{4}$ and concentrated under reduced pressure. The residue was purified using column chromatography (AcOEt $-n$-hexane $=1: 8$ ) and acetal $(23 \mathrm{~g}, 80 \%)$ was obtained as a white powder.

$\mathrm{mp} 166-168^{\circ} \mathrm{C}$ (AcOEt- $n$-hexane); $[\alpha]_{\mathrm{D}}^{27}-92.3 \quad(c=0.48$, $\mathrm{CHCl}_{3}$ ); Anal. Calcd for $\mathrm{C}_{21} \mathrm{H}_{32} \mathrm{O}_{3}: \mathrm{C}, 75.86 ; \mathrm{H}, 9.70$. Found: $\mathrm{C}$, 75.82; H, 9.60.

$(8 R, 9 S, 10 R, 13 S, 14 S)-10,13-D i m e t h y l-1,6,7,8,9,10,11,12,13$, $14,15,16$-dodecahyd rospiro[cyclopenta $[a]$ phenanthrene17,2'-[1,3]dioxolan]-3(2H)-one Under nitrogen atmosphere, $\mathrm{Al}(\mathrm{O} i-\mathrm{Pr})_{3}(2.6 \mathrm{~g}, 12.7 \mathrm{mmol})$ and cyclohexanone $(39.7 \mathrm{~mL}, \mathrm{~d}$ $0.95,383 \mathrm{mmol})$ were added to a toluene $(255 \mathrm{~mL})$ solution of acetal $(8.5 \mathrm{~g}, 25.5 \mathrm{mmol})$ at r.t. After the $2 \mathrm{~h}$ reflux, the reaction mixture was cooled to r.t. and added satd aqueous potas- 
sium sodium tartrate. The aqueous layer was extracted with AcOEt and the combined extract was dried over $\mathrm{MgSO}_{4}$. The concentrated residue was purified by column chromatography (AcOEt $-n$-hexane $=1: 3$ ) to give enone $(8.2 \mathrm{~g}, 97 \%$ ) as colorless crystals.

$\mathrm{mp} 148-149^{\circ} \mathrm{C}$ (AcOEt- $n$-hexane); $[\alpha]_{\mathrm{D}}^{27}+62.2 \quad(c=0.49$, $\mathrm{CHCl}_{3}$ ); Anal. Calcd for $\mathrm{C}_{21} \mathrm{H}_{30} \mathrm{O}_{3}: \mathrm{C}, 76.33 ; \mathrm{H}, 9.15$. Found: C, $76.17 ; \mathrm{H}, 8.98$.

$(5 S, 8 R, 9 S, 10 S, 13 S, 14 S)$-10,13-Dimethyltetradecahydrospiro[cyclopenta $[a]$ phenanthrene-17, $2^{\prime}-[1,3]$ dioxolan]3(2H)-one (7) Under a nitrogen atmosphere, a lithium wire $(1.0 \mathrm{~g}, 144 \mathrm{mmol})$ was added to liquid ammonia $(300 \mathrm{~mL})$ at $-78^{\circ} \mathrm{C}$. To the reaction mixture was added the solution of enone $(4.0 \mathrm{~g}, 12.1 \mathrm{mmol})$ in tetrahydrofuran (THF) $(150 \mathrm{~mL})$ and stirred for $30 \mathrm{~min}$. After the substrate disappearance was monitored by TLC, solid $\mathrm{NH}_{4} \mathrm{Cl}$ was added until the mixture turned white suspension. The mixture was allowed to r.t. and the liquid ammonia was evaporated through the night. The residue was suspended with $\mathrm{CH}_{2} \mathrm{Cl}_{2}$ and filtrated. The concentrated residue was purified by column chromatography (AcOEt $-n$-hexane $=1: 3$ ) to give compound $7(3.5 \mathrm{~g}, 88 \%)$ as white crystals.

mp 203-204 ${ }^{\circ} \mathrm{C}(\mathrm{MeOH}) ;[\alpha]_{\mathrm{D}}^{28}+2.1\left(c=0.47, \mathrm{CHCl}_{3}\right) ;$ Anal. Calcd for $\mathrm{C}_{21} \mathrm{H}_{32} \mathrm{O}_{3}$ : C, 75.86; H, 9.70. Found: C, 75.96; H, 9.91.

Methyl 2-((5S,8R,9S,10S,13S,14S)-10,13-Dimethyltetradecahydrospiro[cyclopenta $[a]$ phenanthrene-17, $2^{\prime}-[1,3]-$ dioxolan]-3(2H)-ylidene)acetate (8a) To a suspension of $t$-BuOK $(5.3 \mathrm{~g}, 47.5 \mathrm{mmol})$ in anhydrous DMF $(95 \mathrm{~mL})$ was added methyl diethylphosphonoacetate $(10.5 \mathrm{~mL}, \mathrm{~d} 1.15$, $57.0 \mathrm{mmol}$ ) at r.t. and stirred for $1 \mathrm{~h}$ under a nitrogen atmosphere. The mixture was cooled to $0^{\circ} \mathrm{C}$ and added the solution of $7(6.3 \mathrm{~g}, 19.0 \mathrm{mmol})$ in anhydrous DMF $(95 \mathrm{~mL})$ and stirred for $12.5 \mathrm{~h}$. The reaction mixture was poured into water and extracted with $\mathrm{Et}_{2} \mathrm{O}$. The combined extracts were washed with brine, dried over $\mathrm{MgSO}_{4}$ and concentrated under the reduced pressure. The residue was purified by column chromatography (AcOEt- $n$-hexane $=1: 6)$ to give compound 8a $(7.1 \mathrm{~g}, 97 \%)$ as a white powder.

mp $199-201^{\circ} \mathrm{C}(\mathrm{MeOH}) ;[\alpha]_{\mathrm{D}}^{28}+68.8\left(c=0.16, \mathrm{CHCl}_{3}\right) ; \mathrm{IR}$ $\left(\mathrm{CHCl}_{3}\right) \mathrm{cm}^{-1}: 2945,1705,1643,1204,1165 ;{ }^{1} \mathrm{H}-\mathrm{NMR}\left(\mathrm{CDCl}_{3}\right.$, $400 \mathrm{MHz}) \delta: 5.59(\mathrm{t}, 1 \mathrm{H}, J=1.6 \mathrm{~Hz}), 4.04-3.80(\mathrm{~m}, 4 \mathrm{H}), 3.67$ (s, 3H), 2.44-2.26 (m, 1H), 2.22-2.08 (m, 1H), 2.06-0.45 (m, $20 \mathrm{H}), 0.94$ (s, 3H), 0.85 (s, 3H); ${ }^{13} \mathrm{C}-\mathrm{NMR}\left(\mathrm{CDCl}_{3}, 100 \mathrm{MHz}\right)$ $\delta: 167.0,163.5,119.3,112.1,65.2,64.6,54.1,50.8,50.4,47.6$, $46.0,40.2,36.2,35.8,34.3,33.7,32.3,31.4,30.8,29.0,22.8$, 20.7, 14.6, 12.1; HR-MS (EI) Calcd for $\mathrm{C}_{24} \mathrm{H}_{36} \mathrm{O}_{4} \mathrm{~m} / z\left[\mathrm{M}^{+}\right]$: 388.2614. Found 388.2612; Anal. Calcd for $\mathrm{C}_{24} \mathrm{H}_{36} \mathrm{O}_{4}$ : C, 74.19; H, 9.34. Found: C, 74.04; H, 9.59.

Methyl 2-((3S,5S,8R,9S,10S,13S,14S)-10,13-Dimethyl-17oxohexadecahydro- $1 H$-cyclopenta $[a]$ phenanthren-3-yl)acetate (10) To a suspension of $\mathbf{8 a}(7.1 \mathrm{~g}, 18.3 \mathrm{mmol})$ in $1: 1$ $\mathrm{EtOH} / \mathrm{H}_{2} \mathrm{O}(184 \mathrm{~mL})$ was added $\mathrm{KOH}(10.3 \mathrm{~g}, 183 \mathrm{mmol})$ and the mixture was heated at $90^{\circ} \mathrm{C}$ for $1.5 \mathrm{~h}$. The reaction mixture was concentrated and neutralized with dilute $\mathrm{HCl}$ on the ice bath. The mixture was extracted with $\mathrm{CH}_{2} \mathrm{Cl}_{2}$, and the combined organic layer was dried over $\mathrm{MgSO}_{4}$. The filtrate was concentrated to obtain the crude $\alpha, \beta$-unsaturated carboxylic acid $\mathbf{8 b}$.

Under the nitrogen atmosphere, a lithium wire $(1.3 \mathrm{~g}$, $187 \mathrm{mmol})$ was added to liquid ammonia $(30 \mathrm{~mL})$ at $-78^{\circ} \mathrm{C}$. To the mixture was added the solution of the above crude $\alpha, \beta$-unsaturated carboxylic acid $\mathbf{8 b}$ in 1,4-dioxane $(95 \mathrm{~mL})$, THF $(95 \mathrm{~mL})$ and $t$-BuOH $(7.1 \mathrm{~mL}, \mathrm{~d} 0.78,74.2 \mathrm{mmol})$. After $3 \mathrm{~h}$ stirring, $\mathrm{MeOH}$ was added until the mixture turned white suspension. The mixture was allowed to r.t. and the liquid ammonia was evaporated through the night. The residue was suspended with $\mathrm{CH}_{2} \mathrm{Cl}_{2}$ and filtrated. The solution was acidified using dilute $\mathrm{HCl}$ and the water layer was extracted by $\mathrm{CH}_{2} \mathrm{Cl}_{2}$. The combined organic layer was dried over $\mathrm{MgSO}_{4}$ and the concentrated residue was evaporated to give the crude carboxylic acid $\mathbf{9 b}$. The ratio of isomers was determined the benzyl esters of $\mathbf{9 b}$ by ${ }^{1} \mathrm{H}-\mathrm{NMR}$.

Under the nitrogen atmosphere, sodium hydride $(\mathrm{NaH})$ $(2.2 \mathrm{~g}, 60 \%$ oil suspension, $54.9 \mathrm{mmol})$ was added to the above crude carboxylic acid $\mathbf{9 b}$ in anhydrous DMF $(183 \mathrm{~mL})$ at r.t. After the reaction mixture was stirred for $1 \mathrm{~h}$, methyl iodide (MeI) $(8.0 \mathrm{~mL}, 54.9 \mathrm{mmol})$ was added and the reaction mixture was stirred overnight. The reaction was concentrated, diluted by $\mathrm{Et}_{2} \mathrm{O}$ and washed with $\mathrm{H}_{2} \mathrm{O}$. The organic layer was dried over $\mathrm{MgSO}_{4}$ and concentrated to give crude methyl ester.

To the above crude methyl ester in THF $(183 \mathrm{~mL})$ was added $1.5 \mathrm{~N} \mathrm{HCl}(245 \mathrm{~mL})$ using the dropping funnel at $0^{\circ} \mathrm{C}$ and the mixture was stirred for $4 \mathrm{~h}$ at r.t. The reaction mixture was neutralized with $10 \% \mathrm{NaOH}$ and concentrated under reduced pressure. The residue was extracted with AcOEt and the organic layer was dried over $\mathrm{MgSO}_{4}$. The concentrated residue was purified by column chromatography (AcOEt $-n$ hexane $=1: 7)$ to give compound $\mathbf{1 0}(5.8 \mathrm{~g}, 91 \%, 4$ steps $)$ as a white powder.

$\mathrm{mp} \quad 110-115^{\circ} \mathrm{C}$ (AcOEt- $n$-hexane); $[\alpha]_{\mathrm{D}}^{28}+74.3 \quad(c=0.50$, $\left.\mathrm{CHCl}_{3}\right)$; IR $\left(\mathrm{CHCl}_{3}\right) \mathrm{cm}^{-1}: 3012,2920,2855,1728,1439$; ${ }^{1} \mathrm{H}-\mathrm{NMR}\left(\mathrm{CDCl}_{3}, 400 \mathrm{MHz}\right) \delta: 3.64(\mathrm{~s}, 3 \mathrm{H}), 2.41(\mathrm{dd}, 1 \mathrm{H}$, $J=19.0,8.7 \mathrm{~Hz}$ ), 2.18 (d, 2H, $J=7.1 \mathrm{~Hz}), 1.91$ (dt, 1H, $J=19.0$, $9.0 \mathrm{~Hz}), 1.97-1.86(\mathrm{~m}, 1 \mathrm{H}), 1.86-0.60(\mathrm{~m}, 20 \mathrm{H}), 0.84(\mathrm{~s}, 3 \mathrm{H})$, $0.77(\mathrm{~s}, 3 \mathrm{H}) ;{ }^{13} \mathrm{C}-\mathrm{NMR}\left(\mathrm{CDCl}_{3}, 100 \mathrm{MHz}\right) \delta: 220.9,173.2,54.6$, 51.5, 51.4, 47.8, 46.4, 41.8, 38.3, 36.0, 35.9, 35.24, 35.21, 35.1, 31.7, 31.0, 28.59, 28.57, 21.9, 20.4, 13.9, 12.4; HR-MS (EI) Calcd for $\mathrm{C}_{22} \mathrm{H}_{34} \mathrm{O}_{3} \mathrm{~m} / z\left[\mathrm{M}^{+}\right]$: 346.2508. Found 346.2511.

Methyl 2-((3S,5S,8R,9S,10S,13S,14S)-17-Acetoxy-10,13dimethyl-2,3,4,5,6,7,8,9,10,11,12,13,14,15-tetradecahydro$\mathbf{1 H}$-cyclopenta $[\boldsymbol{a}]$ phenanthren-3-yl)acetate To a solution of $\mathbf{1 0}(6.1 \mathrm{~g}, 17.6 \mathrm{mmol})$ in isopropenyl acetate $(38.4 \mathrm{~mL})$ was added the solution of conc. $\mathrm{H}_{2} \mathrm{SO}_{4}(0.1 \mathrm{~mL})$ in isopropenyl acetate $(5.0 \mathrm{~mL})$ under a nitrogen atmosphere. After stirring for $5.5 \mathrm{~h}$ at $90^{\circ} \mathrm{C}$, above $\mathrm{H}_{2} \mathrm{SO}_{4}$ in isopropenyl acetate $(1.9 \mathrm{~mL})$ was added and then the reaction mixture was stirred for $4.5 \mathrm{~h}$ at same temperature. The reaction mixture was diluted with $\mathrm{Et}_{2} \mathrm{O}$ and neutralized with satd aqueous $\mathrm{NaHCO}_{3}$ at $0^{\circ} \mathrm{C}$. The mixture was extracted with $\mathrm{Et}_{2} \mathrm{O}$ and the combined organic layer was dried over $\mathrm{MgSO}_{4}$. The concentrated residue was purified by column chromatography (AcOEt $-n$-hexane $=1: 15$ ) to give acetate $(5.2 \mathrm{~g}, 75 \%)$ as a white solid.

IR $\left(\mathrm{CHCl}_{3}\right) \mathrm{cm}^{-1}: 2920,2855,1732,1229,1202 ;{ }^{1} \mathrm{H}-\mathrm{NMR}$ $\left(\mathrm{CDCl}_{3}, 400 \mathrm{MHz}\right) \delta: 5.44(\mathrm{dd}, 1 \mathrm{H}, J=2.9,1.5 \mathrm{~Hz}), 3.65$ (s, $3 \mathrm{H}), 2.29-2.07(\mathrm{~m}, 1 \mathrm{H}), 2.19$ (d, 2H, J=7.1 Hz), 2.13 (s, 3H), $1.98-0.67(\mathrm{~m}, 20 \mathrm{H}), 0.87(\mathrm{~s}, 3 \mathrm{H}), 0.77(\mathrm{~s}, 3 \mathrm{H}) ;{ }^{13} \mathrm{C}-\mathrm{NMR}$ $\left(\mathrm{CDCl}_{3}, 100 \mathrm{MHz}\right) \delta: 173.2,168.6,159.5,111.1,55.1,54.2,51.4$, 46.7, 44.9, 41.9, 38.1, 36.1, $35.3(\mathrm{CH}), 35.3\left(\mathrm{CH}_{2}\right), 33.7,33.5$, 31.2, 29.0, 28.7, 28.6, 21.3, 20.6, 15.7, 12.4; HR-MS (EI) Calcd for $\mathrm{C}_{24} \mathrm{H}_{36} \mathrm{O}_{4} \mathrm{~m} / z\left[\mathrm{M}^{+}\right]$: 388.2614. Found 388.2617.

Methyl (1S,2S,4a $S, 4 \mathrm{~b} S, 7 S, 8 \mathrm{a} S, 10 \mathrm{a} R)$-7-(2-Methoxy-2oxoethyl)-2,4b-dimethyl-1-(2-oxoethyl)tetradecahydrophen- 
anthrene-2-carboxylate (11) To a solution of acetate $(1.0 \mathrm{~g}$, $2.6 \mathrm{mmol})$ and $\mathrm{AcOH}(2.1 \mathrm{~mL})$ in $\mathrm{CH}_{2} \mathrm{Cl}_{2}(26 \mathrm{~mL})$ was bubbled with ozone at $-78^{\circ} \mathrm{C}$ for $3 \mathrm{~h}$. The dissolved ozone gas was removed by Ar bubbling through the solution. Then $\mathrm{Me}_{2} \mathrm{~S}$ $(3.0 \mathrm{~mL}, \mathrm{~d} 0.85,41.0 \mathrm{mmol})$ was added to the mixture, and the resulting mixture was stirred at $0^{\circ} \mathrm{C}$ for $6.5 \mathrm{~h}$. After addition of $\mathrm{AcOH}(24 \mathrm{~mL})$ and $\mathrm{H}_{2} \mathrm{O}(8 \mathrm{~mL})$, the mixture was stirred at r.t. for $1 \mathrm{~d}$. The reaction mixture was added $\mathrm{H}_{2} \mathrm{O}$ and extracted with $\mathrm{CH}_{2} \mathrm{Cl}_{2}$. The organic layer was dried over $\mathrm{MgSO}_{4}$ and concentrated in vacuo. The residue was diluted with $\mathrm{Et}_{2} \mathrm{O}$, and a solution of $\mathrm{CH}_{2} \mathrm{~N}_{2}$ in $\mathrm{Et}_{2} \mathrm{O}$ was added until the resulting solution turned to yellow. The mixture was warmed to r.t. and stirred overnight. The concentrated residue was purified by column chromatography $\left(\mathrm{Et}_{2} \mathrm{O}-n\right.$-hexane $\left.=1: 5\right)$ to give compound 11 ( $845 \mathrm{mg}, 83 \%$ in 2 steps) as a white solid.

$\mathrm{mp} 68-70^{\circ} \mathrm{C}$ (AcOEt-n-hexane); IR $\left(\mathrm{CHCl}_{3}\right) \mathrm{cm}^{-1}: 3026$, 2949, 2855, 1721, 1435; $[\alpha]_{\mathrm{D}}^{27}-26.6\left(c=0.36, \mathrm{CHCl}_{3}\right) ;{ }^{1} \mathrm{H}-\mathrm{NMR}$ $\left(\mathrm{CDCl}_{3}, 400 \mathrm{MHz}\right) \delta: 9.68(\mathrm{~d}, 1 \mathrm{H}, J=3.2 \mathrm{~Hz}), 3.654(\mathrm{~s}, 3 \mathrm{H})$, 3.646 (s, 3H), 2.42-2.31 (m, 1H), 2.27 (ddd, 1H, J=17.2, 7.2, $3.2 \mathrm{~Hz}), 2.19$ (d, 2H, $J=6.8 \mathrm{~Hz}), 2.10(\mathrm{dd}, 1 \mathrm{H}, J=17.2,2.2 \mathrm{~Hz})$, $1.88-0.67(\mathrm{~m}, 18 \mathrm{H}), 1.11(\mathrm{~s}, 3 \mathrm{H}), 0.72(\mathrm{~s}, 3 \mathrm{H}) .{ }^{13} \mathrm{C}-\mathrm{NMR}$ $\left(\mathrm{CDCl}_{3}, 100 \mathrm{MHz}\right) \delta: 201.9,178.1,173.2,53.3,52.0,51.4,47.4$, 46.7, 45.8, 41.8, 41.7, 38.1, 37.4, 36.7, 35.9, 35.2, 35.0, 31.9, 28.7, 28.5, 19.8, 15.6, 12.3; HR-MS (FAB) Calcd for $\mathrm{C}_{23} \mathrm{H}_{37} \mathrm{O}_{5} \mathrm{~m} / \mathrm{z}$ $\left[\mathrm{MH}^{+}\right]$: 393.2641. Found 393.2641.

Methyl (1S,2S,4a $S, 4 \mathrm{~b} S, 7 S, 8 \mathrm{a} S, 10 \mathrm{a} R)-1-(3-C y a n o a l l y l)-$ 7-(2-methoxy-2-oxoethyl)-2,4b-dimethyltetradecahydrophenanthrene-2-carboxylate (12) To a suspension of $\mathrm{KO}^{t} \mathrm{Bu}(44.0 \mathrm{mg}, 0.38 \mathrm{mmol})$ in DMF $(640 \mu \mathrm{L})$ was added diethyl cyanomethylphosphonate $(59.6 \mu \mathrm{L}, \mathrm{d} 1.13,0.38 \mathrm{mmol})$ and the mixture was stirred at $0^{\circ} \mathrm{C}$ for $1 \mathrm{~h}$ under a nitrogen atmosphere. To the solution was added compound $11(50.0 \mathrm{mg}$, $0.13 \mathrm{mmol})$ in anhydrous DMF $(640 \mu \mathrm{L})$ and stirred at r.t. for $10 \mathrm{~h}$. The reaction mixture was poured into $\mathrm{H}_{2} \mathrm{O}$ and extracted with $\mathrm{Et}_{2} \mathrm{O}$. The combined extract was dried over $\mathrm{MgSO}_{4}$ and concentrated. The residue was purified by column chromatography $\left(\mathrm{Et}_{2} \mathrm{O}-n\right.$-hexane $\left.=1: 3\right)$ to give compound $12(50.5 \mathrm{mg}$, $96 \%$ ) as white amorphous.

IR $\left(\mathrm{CHCl}_{3}\right) \mathrm{cm}^{-1}:$ 2949, 2922, 2224, 1721, 1630, 1435, 1236; $[\alpha]_{\mathrm{D}}^{27}-28.2\left(c=0.24, \mathrm{CHCl}_{3}\right) ;{ }^{1} \mathrm{H}-\mathrm{NMR}\left(\mathrm{CDCl}_{3}, 300 \mathrm{MHz}\right.$, $E: Z=1: 1.8) \delta: 6.70(\mathrm{dt}, 0.36 \mathrm{H}, J=16.5,7.2 \mathrm{~Hz}), 6.49$ (ddd, $0.64 \mathrm{H}, J=10.9,6.8,6.6 \mathrm{~Hz}), 5.28(\mathrm{dt}, 0.36 \mathrm{H}, J=16.5,1.7 \mathrm{~Hz})$, $5.21(\mathrm{dt}, 0.64 \mathrm{H}, J=10.9,1.7 \mathrm{~Hz}), 3.670(\mathrm{~s}, 1.1 \mathrm{H}), 3.665(\mathrm{~s}$, $1.9 \mathrm{H}), 3.663(\mathrm{~s}, 1.9 \mathrm{H}), 3.661(\mathrm{~s}, 1.1 \mathrm{H}), 2.51-2.30(\mathrm{~m}, 0.64 \mathrm{H})$, 2.26-2.09 (m, 1H), $2.20(\mathrm{~d}, 2 \mathrm{H}, J=7.0 \mathrm{~Hz}), 2.08-1.95(\mathrm{~m}$, $0.36 \mathrm{H}), 1.91-0.73(\mathrm{~m}, 19 \mathrm{H}), 1.15(\mathrm{~s}, 1.9 \mathrm{H}), 1.10(\mathrm{~s}, 1.1 \mathrm{H})$, $0.74(\mathrm{~s}, 1.9 \mathrm{H}), 0.73(\mathrm{~s}, 1.1 \mathrm{H}) ;{ }^{13} \mathrm{C}-\mathrm{NMR}\left(\mathrm{CDCl}_{3}, 100 \mathrm{MHz}\right.$, $E: Z=1: 5.5) \delta: 178.2,172.9,155.7,115.7,98.2,53.3,51.7,51.2$, $47.4,46.9,45.6,41.6,38.0,37.3,37.2,35.8,35.0,34.9,34.3$, $31.5,28.6,28.3,19.6,15.2,12.2$; HR-MS (FAB) Calcd for $\mathrm{C}_{25} \mathrm{H}_{38} \mathrm{NO}_{4} \mathrm{~m} / z\left[\mathrm{MH}^{+}\right]:$416.2801. Found 416.2806.

Methyl (1S,2S,4a $S, 4 \mathrm{~b} S, 7 S, 8 \mathrm{a} S, 10 \mathrm{a} R)-1-(4-(($ tert-Butoxycarbonyl)amino)butyl)-7-(2-methoxy-2-oxoethyl)-2,4bdimethyltetradecahydrophenanthrene-2-carboxylate Under a hydrogen atmosphere (10 atm), the suspension of compound 12 (144 mg, $0.35 \mathrm{mmol}), \mathrm{Pt}_{2} \mathrm{O}(27 \mathrm{mg})$ and $10 \%$ $\mathrm{HCl}-\mathrm{MeOH}(9.0 \mathrm{~mL})$ in $\mathrm{CHCl}_{3}(6.0 \mathrm{~mL})$ was stirred at for $11.5 \mathrm{~h}$ in an autoclave at r.t. The reaction mixture was filtered through a Celite pad and the filtrate was concentrated. The residue was dissolved in $\mathrm{CH}_{2} \mathrm{Cl}_{2}(4.0 \mathrm{~mL})$ and added $\mathrm{Et}_{3} \mathrm{~N}(146 \mu \mathrm{L}, \mathrm{d} 0.73,1.05 \mathrm{mmol})$ and $\mathrm{Boc}_{2} \mathrm{O}(161 \mu \mathrm{L}, \mathrm{d} 0.95$,
$0.70 \mathrm{mmol})$. After $7 \mathrm{~h}$ stirring, the reaction mixture was washed with $\mathrm{H}_{2} \mathrm{O}$ and dried over $\mathrm{MgSO}_{4}$. The concentrated residue was purified by column chromatography (AcOEt- $n$ hexane $=1: 5)$ to give compound $\mathbf{1 3}(174 \mathrm{mg}, 95 \%, 2$ steps $)$ as a pale yellow oil.

$[\alpha]_{\mathrm{D}}^{28}-16.7\left(c=0.46, \mathrm{CHCl}_{3}\right) ; \mathrm{IR}\left(\mathrm{CHCl}_{3}\right) \mathrm{cm}^{-1}: 3453,3024$, 2928, 2857, 2359, 1715, 1506; ${ }^{1} \mathrm{H}-\mathrm{NMR}\left(\mathrm{CDCl}_{3}, 300 \mathrm{MHz}\right) \delta$ : 4.49 (br, $1 \mathrm{H}), 3.64$ (s, 3H), 3.63 (s, 3H), 3.03 (dd, $2 \mathrm{H}, J=11.8$, $6.3 \mathrm{~Hz}), 2.18(\mathrm{~d}, 2 \mathrm{H}, J=6.9 \mathrm{~Hz}), 2.00-0.50(\mathrm{~m}, 25 \mathrm{H}), 1.42(\mathrm{~s}$, 9H), $1.05(\mathrm{~s}, 3 \mathrm{H}), 0.70(\mathrm{~s}, 3 \mathrm{H}) ;{ }^{13} \mathrm{C}-\mathrm{NMR}\left(\mathrm{CDCl}_{3}, 100 \mathrm{MHz}\right)$ $\delta: 179.2,173.5,155.9,78.9,53.3,51.5,51.3,47.7,47.5,45.8$, $41.7,40.3,38.0,37.7,36.9,35.8,35.1,35.0,31.8,31.6,30.5$, 28.8, 28.4, 28.4, 27.6, 19.6, 15.1, 12.2; HR-MS (EI) Calcd for $\mathrm{C}_{30} \mathrm{H}_{51} \mathrm{NO}_{6} \mathrm{~m} / \mathrm{z}\left[\mathrm{M}^{+}\right]:$521.3716. Found 522.3797.

2-((2S,4a $S, 4 \mathrm{~b} S, 7 S, 8 S, 8 \mathrm{a} R, 10 \mathrm{a} S)-8-(4-(($ tert-Butoxycarbonyl)amino)butyl)-7-(methoxycarbonyl)-4a,7-dimethyltetradecahydrophenanthren-2-yl)acetic Acid To a solution of 13 (400 mg, $0.77 \mathrm{mmol}$ ) and $\mathrm{Bu}_{4} \mathrm{NHSO}_{4}(40 \mathrm{mg})$ in $1: 1 \mathrm{MeOH} /$ THF $(15.4 \mathrm{~mL})$ was added $10 \% \mathrm{LiOH}(3.6 \mathrm{~mL}, 15.2 \mathrm{mmol})$ and stirred at r.t. for $3.5 \mathrm{~h}$. The mixture was concentrated in vacuo and dilute with $\mathrm{CH}_{2} \mathrm{Cl}_{2}$. The mixture was neutralized with $10 \% \mathrm{KHSO}_{4}$ and the aqueous layer was extracted with $\mathrm{CH}_{2} \mathrm{Cl}_{2}$. The concentrated residue was purified by column chromatography $\left(\mathrm{CH}_{2} \mathrm{Cl}_{2}-\mathrm{MeOH}=10: 1\right)$ to give a desired carboxylic acid (389 mg, quant.) as a white amorphous.

${ }^{1} \mathrm{H}-\mathrm{NMR}\left(\mathrm{CDCl}_{3}, 300 \mathrm{MHz}\right) \delta: 4.51(\mathrm{br}, 1 \mathrm{H}), 3.64$ (s, $3 \mathrm{H}), 3.04(\mathrm{dd}, 2 \mathrm{H}, J=11.6,6.2 \mathrm{~Hz}), 2.22$ (d, $2 \mathrm{H}, J=6.9 \mathrm{~Hz})$, 1.95-0.65 (m, 25H), 1.43 (s, 9H), 1.11 (s, 3H), 0.72 (s, 3H); ${ }^{13} \mathrm{C}-\mathrm{NMR}\left(\mathrm{CDCl}_{3}, 100 \mathrm{MHz}\right) \delta: 179.0,178.2,155.7,79.0,53.4$, 51.6, 47.9, 47.6, 46.0, 41.8, 40.4, 38.2, 37.9, 37.0, 36.0, 35.1, $35.0,32.0,31.8,30.7,29.0,28.5,28.5,27.8,19.8,15.3,12.4$.

2-((2S,4a $S, 4 \mathrm{~b} S, 7 S, 8 S, 8 \mathrm{a} R, 10 \mathrm{a} S)-8-(4-G u a n i d i n o b u t y l)-$ 7-(methoxycarbonyl)-4a,7-dimethyltetradecahydrophenanthren-2-yl)acetic Acid (3a) To a solution of the above carboxylic acid $(350 \mathrm{mg}, 0.71 \mathrm{mmol})$ in $\mathrm{CH}_{2} \mathrm{Cl}_{2}(7.1 \mathrm{~mL})$ was added trifluoroacetic acid (TFA) $(5.5 \mathrm{~mL}, \mathrm{~d} 1.48,71 \mathrm{mmol})$ at $0^{\circ} \mathrm{C}$, and the mixture was stirred at r.t. for $4.5 \mathrm{~h}$. The reaction mixture was concentrated, and then pyridine $(7.1 \mathrm{~mL})$ and $N, N^{\prime}$-bis(tert-butoxycarbonyl)-1 $H$-pyrazole-1-carboxamidine $(1.1 \mathrm{~g}, 3.55 \mathrm{mmol})$ was added to the residue. The mixture was stirred for $11 \mathrm{~d}$ and the reaction mixture was diluted with $\mathrm{Et}_{2} \mathrm{O}$. The mixture was neutralized with $10 \% \mathrm{KHSO}_{4}$ and the water layer was extracted by $\mathrm{Et}_{2} \mathrm{O}$. The organic layer was dried over $\mathrm{MgSO}_{4}$ and concentrated in vacuo. The residue was purified by column chromatography $\left(\mathrm{CH}_{2} \mathrm{Cl}_{2}-\mathrm{MeOH}=20: 1\right)$ to give a $N$-Boc guanidine derivative ( $462 \mathrm{mg}, 2$ steps quant.) as white amorphous. To the solution of above compound $(50 \mathrm{mg}$, $0.08 \mathrm{mmol})$ in $\mathrm{CH}_{2} \mathrm{Cl}_{2}(769 \mu \mathrm{L})$ was added TFA $(592 \mu \mathrm{L}$, d $1.48,7.69 \mathrm{mmol})$ at $0^{\circ} \mathrm{C}$ and stirred at r.t. for $5 \mathrm{~h}$. The reaction mixture was concentrated to give crude guanidine $\mathbf{3 a}(30 \mathrm{mg}$, $87 \%, 68 \%$ purity) as a colorless oil.

$[\alpha]_{\mathrm{D}}^{28}-5.75(c=0.72, \mathrm{EtOH}) ; \mathrm{IR}(\mathrm{KBr}) \mathrm{cm}^{-1}: 3354,3171$, 2937, 2857, 1705, 1662, 1451, 1383, 1243, 1148, 1120; ${ }^{1} \mathrm{H}-\mathrm{NMR}\left(\mathrm{CD}_{3} \mathrm{OD}, 50^{\circ} \mathrm{C}, 500 \mathrm{MHz}\right) \delta: 3.64(\mathrm{~s}, 3 \mathrm{H}), 3.11(\mathrm{t}$, $2 \mathrm{H}, J=7.0 \mathrm{~Hz}), 2.15(\mathrm{~d}, 2 \mathrm{H}, J=7.0 \mathrm{~Hz}), 1.92(\mathrm{ddd}, 1 \mathrm{H}, J=12.5$, 6.7, 3.4 Hz), 1.85-0.60 (m, $24 \mathrm{H}), 1.10(\mathrm{~s}, 3 \mathrm{H}), 0.77$ (s, 3H); ${ }^{13} \mathrm{C}-\mathrm{NMR}\left(\mathrm{CD}_{3} \mathrm{OD}, 50^{\circ} \mathrm{C}, 100 \mathrm{MHz}\right) \delta: 180.5,176.5,158.5$, $55.1,52.1,49.0,47.5,42.8,42.4,39.5,39.2,39.1,38.3,37.1$, 36.5, 36.3, 33.4, 32.8, 30.5, 30.2, 29.6, 28.7, 20.9, 15.7, 12.7; HR-MS (FAB) Calcd for $\mathrm{C}_{25} \mathrm{H}_{44} \mathrm{~N}_{3} \mathrm{O}_{4} \mathrm{~m} / z\left[\mathrm{MH}^{+}\right]$: 450.3332 . Found 450.3339 . 
Methyl (1S,2S,4a $S, 4 \mathrm{~b} S, 7 S, 8 \mathrm{a} S, 10 \mathrm{a} R)$-7-(2-Methoxy-2oxoethyl)-1-(3-methoxyallyl)-2,4b-dimethyltetradecahydrophenanthrene-2-carboxylate To a suspension of (methoxymethyl)triphenylphosphonium chloride (263 mg, $0.78 \mathrm{mmol})$ in THF $(2.6 \mathrm{~mL})$ was added LHMDS $(765 \mu \mathrm{L}$, $0.765 \mathrm{mmol}$ ) and stirred at $-78^{\circ} \mathrm{C}$ for $15 \mathrm{~min}$ under a nitrogen atmosphere. After the solution of $11(100 \mathrm{mg}, 0.255 \mathrm{mmol})$ in THF $(2.6 \mathrm{~mL})$ was added to the reaction mixture and stirred for $4.5 \mathrm{~h}$. The reaction was quenched with satd aqueous $\mathrm{NH}_{4} \mathrm{Cl}$ and extracted with $\mathrm{Et}_{2} \mathrm{O}$. The organic layer was washed with brine and dried over $\mathrm{MgSO}_{4}$. The concentrated residue was purified by column chromatography (AcOEt $-n$-hexane $=1: 10)$ to give a desired enol ether $(78.4 \mathrm{mg}, 73 \%$ ) as a colorless oil.

${ }^{1} \mathrm{H}-\mathrm{NMR}\left(\mathrm{CDCl}_{3}, 300 \mathrm{MHz}, E: Z=1: 1.2\right) \delta: 6.16(\mathrm{~d}, 0.46 \mathrm{H}$, $J=12.6 \mathrm{~Hz}), 5.74(\mathrm{dt}, 0.54 \mathrm{H}, J=6.2,1.6 \mathrm{~Hz}), 4.64(\mathrm{dt}, 0.46 \mathrm{H}$, $J=12.6,7.6 \mathrm{~Hz}), 4.28(\mathrm{dd}, 0.54 \mathrm{H}, J=13.6,7.1 \mathrm{~Hz}), 3.66(\mathrm{~s}, 3 \mathrm{H})$, $3.631(\mathrm{~s}, 1.4 \mathrm{H}), 3.625(\mathrm{~s}, 1.6 \mathrm{H}), 3.55(\mathrm{~s}, 1.6 \mathrm{H}), 3.47(\mathrm{~s}, 1.4 \mathrm{H})$, $2.20(\mathrm{~d}, 2 \mathrm{H}, J=6.9 \mathrm{~Hz}), 2.14-0.52(\mathrm{~m}, 21 \mathrm{H}), 1.11(\mathrm{~s}, 1.6 \mathrm{H})$, $1.10(\mathrm{~s}, 1.4 \mathrm{H}), 0.73(\mathrm{~s}, 3 \mathrm{H}) ;{ }^{13} \mathrm{C}-\mathrm{NMR}\left(\mathrm{CDCl}_{3}, 100 \mathrm{MHz}\right.$, $E: Z=1: 1.2) \quad \delta: 179.1(Z), 179.0(E), 173.23(Z), 173.21(E)$, $147.0(E), 145.0(Z), 106.9(Z), 102.8(E), 59.4,55.9,53.5,51.5$ $(Z), 51.4(E), 48.0(E), 47.5(Z), 47.1,45.9(0.54), 45.8(E)$, 41.8, 38.2, $37.9(E), 37.7(Z), 37.4(0.54), 37.3(E), 36.0,35.21$ $(Z), 35.20(E), 35.16(Z), 35.12(E), 31.8(E), 31.5(0.54), 29.2$ $(E), 28.93(Z), 28.91(E), 28.6(Z), 25.8,19.93(E), 19.90(Z)$, $15.4(E), 15.3(Z), 12.3$; HR-MS (FAB) Calcd for $\mathrm{C}_{25} \mathrm{H}_{41} \mathrm{O}_{5} \mathrm{~m} / \mathrm{z}$ $\left[\mathrm{MH}^{+}\right]$: 421.2954. Found 421.2963.

Methyl (1S,2S,4a $S, 4 \mathrm{~b} S, 7 S, 8 \mathrm{a} S, 10 \mathrm{a} R)$-7-(2-Methoxy-2oxoethyl)-2,4b-dimethyl-1-(3-oxopropyl)tetradecahydrophenanthrene-2-carboxylate (14) To a solution of the enol ether $(114 \mathrm{mg}, 0.271 \mathrm{mmol})$ in acetone $(9 \mathrm{~mL})-\mathrm{H}_{2} \mathrm{O}(300 \mu \mathrm{L})$ was added $\mathrm{Ts} O H \cdot \mathrm{H}_{2} \mathrm{O}(262 \mathrm{mg}, 1.35 \mathrm{mmol})$ at $0^{\circ} \mathrm{C}$ and stirred at r.t. for overnight. The reaction mixture was neutralized with satd aqueous $\mathrm{NaHCO}_{3}$ and extracted with $\mathrm{Et}_{2} \mathrm{O}$. The combined organic layer was washed with brine and dried over $\mathrm{MgSO}_{4}$. The concentrated residue was purified by column chromatography (AcOEt $-n$-hexane $=1: 5)$ to give compound 14 (80.0 mg, $73 \%)$ as a colorless oil.

IR $\left(\mathrm{CHCl}_{3}\right) \mathrm{cm}^{-1}:$ 3516, 2949, 2922, 2727, 1732, 1711, 1385, 1238; ${ }^{1} \mathrm{H}-\mathrm{NMR}\left(\mathrm{CDCl}_{3}, 300 \mathrm{MHz}\right) \delta: 9.62(\mathrm{t}, 1 \mathrm{H}, J=1.4 \mathrm{~Hz})$, $3.62(\mathrm{~s}, 3 \mathrm{H}), 3.62$ (s, 3H), $2.43(\mathrm{td}, 2 \mathrm{H}, J=7.8,1.4 \mathrm{~Hz}), 2.16(\mathrm{~d}$, $2 \mathrm{H}, J=7.2 \mathrm{~Hz}$ ), $1.82-0.73(\mathrm{~m}, 21 \mathrm{H}), 1.08$ (s, 3H), 0.70 (s, 3H); ${ }^{13} \mathrm{C}-\mathrm{NMR}\left(\mathrm{CDCl}_{3}, 100 \mathrm{MHz}\right) \delta: 201.8,178.6,173.1,53.3,51.7$, 51.3, 47.8, 46.7, 45.8, 45.0, 41.7, 38.1, 37.9, 37.2, 35.9, 35.1, 35.0, 31.9, 28.8, 28.5, 24.0, 19.7, 15.2, 12.3; HR-MS (EI) Calcd for $\mathrm{C}_{24} \mathrm{H}_{38} \mathrm{O}_{5} \mathrm{~m} / z\left[\mathrm{M}^{+}\right]:$406.2719. Found 406.2717.

Methyl (1S,2S,4a $S, 4 \mathrm{~b} S, 7 S, 8 \mathrm{a} S, 10 \mathrm{a} R)-1-(3-(($ tert-Butoxycarbonyl)amino)propyl)-7-(2-methoxy-2-oxoethyl)-2,4bdimethyltetradecahydrophenanthrene-2-carboxylate To a solution of $\mathbf{1 4}(355 \mathrm{mg}, 0.87 \mathrm{mmol})$ in EtOH $(9 \mathrm{~mL})$ was added $\mathrm{Et}_{3} \mathrm{~N}(487 \mu \mathrm{L}, \mathrm{d} 0.73,3.49 \mathrm{mmol})$ and hydroxylamine hydrochloride $(152 \mathrm{mg}, 2.18 \mathrm{mmol})$ and stirred vigorously at r.t. for $2.5 \mathrm{~h}$. The reaction mixture was diluted with $\mathrm{Et}_{2} \mathrm{O}$ and washed with water and brine. The organic layer was dried over $\mathrm{MgSO}_{4}$ and concentrated in vacuo to give crude oxime. Under a hydrogen atmosphere (30 atm), a suspension of the crude oxime $(165 \mathrm{mg}, 0.39 \mathrm{mmol}), \mathrm{PtO}_{2}(16.5 \mathrm{mg})$ in $\mathrm{AcOH}$ $(15 \mathrm{~mL})$ was vigorously stirred at r.t. for $10 \mathrm{~h}$ in an autoclave. The reaction mixture was filtered through a Celite pad and concentrated. The residue was dissolved in $\mathrm{CH}_{2} \mathrm{Cl}_{2}(4.0 \mathrm{~mL})$ and added $\mathrm{Et}_{3} \mathrm{~N}(163 \mu \mathrm{L}, \mathrm{d} 0.73,1.17 \mathrm{mmol})$ and $\mathrm{Boc}_{2} \mathrm{O}$
$(179 \mu \mathrm{L}, \mathrm{d} 0.95,0.78 \mathrm{mmol})$. After $2 \mathrm{~h}$ stirring, the reaction mixture was washed with $\mathrm{H}_{2} \mathrm{O}$ and dried over $\mathrm{MgSO}_{4}$. The concentrated residue was purified by column chromatography (AcOEt- $n$-hexane $=1: 5)$ to give compound 15 (155 mg, 78\%) as a white amorphous.

$[\alpha]_{\mathrm{D}}^{27}+18.2\left(c=0.51, \mathrm{CHCl}_{3}\right) ; \mathrm{IR}\left(\mathrm{CHCl}_{3}\right) \mathrm{cm}^{-1}: 3455,2947$, 2924, 1715, 1506; ${ }^{1} \mathrm{H}-\mathrm{NMR}\left(\mathrm{CDCl}_{3}, 500 \mathrm{MHz}\right) \delta: 4.66$ (br, $\left.1 \mathrm{H}\right)$, $3.66(\mathrm{~s}, 3 \mathrm{H}), 3.66(\mathrm{~s}, 3 \mathrm{H}), 2.99$ (quintet, $2 \mathrm{H}, J=6.2 \mathrm{~Hz}$ ), 2.20 (d, 2H, J=7.4 Hz), 1.88-0.73 (m, 23H), 1.43 (s, 9H), 1.08 (s, $3 \mathrm{H}), 0.73$ (s, 3H); ${ }^{13} \mathrm{C}-\mathrm{NMR}\left(\mathrm{CDCl}_{3}, 125 \mathrm{MHz}\right) \delta$ : 179.0, 173.3, 155.8, 78.6, 53.2, 51.4, 51.1, 47.7, 47.0, 45.7, 41.6, 40.7, 37.9, $37.7,36.8,35.7,34.94,34.89,31.7,30.6,29.0,28.7,28.3,19.5$, 15.0, 12.1; HR-MS (FAB) Calcd for $\mathrm{C}_{29} \mathrm{H}_{50} \mathrm{NO}_{6} \mathrm{~m} / z\left[\mathrm{MH}^{+}\right]$: 508.3638. Found 508.3637.

2-((2S,4a $S, 4 \mathrm{~b} S, 7 S, 8 S, 8 \mathrm{a} R, 10 \mathrm{a} S)-8-(3-(($ tert-Butoxycarbonyl)amino)propyl)-7-(methoxycarbonyl)-4a,7-dimethyltetradecahydrophenanthren-2-yl)acetic Acid To a solution of $15(126 \mathrm{mg}, 0.25 \mathrm{mmol})$ and $\mathrm{Bu}_{4} \mathrm{NHSO}_{4}(13 \mathrm{mg})$ in $1: 1 \mathrm{MeOH} / \mathrm{THF}(5.0 \mathrm{~mL})$ was added $10 \%$ aqueous $\mathrm{LiOH}$ $(1.2 \mathrm{~mL}, 5.0 \mathrm{mmol})$ and stirred at r.t. overnight. The reaction mixture was concentrated in vacuo and diluted with $\mathrm{CH}_{2} \mathrm{Cl}_{2}$. The solution was neutralized with $10 \%$ aqueous $\mathrm{KHSO}_{4}$ at $0^{\circ} \mathrm{C}$, and the aqueous layer was extracted with $\mathrm{CH}_{2} \mathrm{Cl}_{2}$. The concentrated residue was purified by column chromatography $\left(\mathrm{CH}_{2} \mathrm{Cl}_{2}-\mathrm{MeOH}=20: 1\right)$ to give a desired carboxylic acid (122 mg, quant) as a white amorphous.

$\mathrm{mp} 176-180^{\circ} \mathrm{C}$ (AcOEt- $n$-hexane); $[\alpha]_{\mathrm{D}}^{27}+83.1 \quad(c=0.045$, $\left.\mathrm{CHCl}_{3}\right)$; IR $\left(\mathrm{CHCl}_{3}\right) \mathrm{cm}^{-1}: 3455,2945,2924,2857,1709,1506$; ${ }^{1} \mathrm{H}-\mathrm{NMR}\left(\mathrm{CDCl}_{3}, 400 \mathrm{MHz}\right) \delta: 4.56(\mathrm{br}, 1 \mathrm{H}), 3.66(\mathrm{~s}, 3 \mathrm{H}), 3.00$ (br, 2H), 2.22 (d, 2H, J=5.1 Hz), 1.87-0.68 (m, 23H), 1.43 (s, 9H), 1.08 (s, 3H), 0.73 (s, 3H); ${ }^{13} \mathrm{C}-\mathrm{NMR}\left(\mathrm{CDCl}_{3}, 100 \mathrm{MHz}\right) \delta$ : 179.0, 178.1, 155.7, 79.0, 53.4, 51.7, 47.9, 47.2, 45.9, 41.8, 41.0, $38.2,37.9,37.1,36.0,35.1,35.0,32.0,31.5,30.9,29.3,28.9$, 28.5, 19.8, 15.3, 12.4; HR-MS (FAB) Calcd for $\mathrm{C}_{28} \mathrm{H}_{48} \mathrm{NO}_{6} \mathrm{~m} / \mathrm{z}$ $\left[\mathrm{MH}^{+}\right]$: 494.3482. Found: 494.3477.

2-((2S,4a $S, 4 \mathrm{~b} S, 7 S, 8 S, 8 \mathrm{a} R, 10 \mathrm{aS})-8-(3-((Z)-2,3-\mathrm{Bis}($ tertbutoxycarbonyl)guanidino)-propyl)-7-(methoxycarbonyl)4a,7-dimethyltetradecahydrophenanthren-2-yl)acetic Acid (16) To a solution of the carboxylic acid $(110 \mathrm{mg}, 0.22 \mathrm{mmol})$ in $\mathrm{CH}_{2} \mathrm{Cl}_{2}(2.2 \mathrm{~mL})$ was added TFA $(1.7 \mathrm{~mL}, 22 \mathrm{mmol})$ at $0^{\circ} \mathrm{C}$ and the mixture was stirred at r.t. for $4.5 \mathrm{~h}$. The reaction mixture was concentrated, and then pyridine $(2.2 \mathrm{~mL})$ and $N, N^{\prime}$-bis(tert-butoxycarbonyl)-1 $H$-pyrazole-1-carboxamidine $(140 \mathrm{mg}, 0.44 \mathrm{mmol})$ was added to the residue. The solution was stirred for $6 \mathrm{~d}$ and the reaction mixture was diluted with $\mathrm{Et}_{2} \mathrm{O}$. The mixture was neutralized with $10 \%$ aqueous $\mathrm{KHSO}_{4}$, and the aqueous layer was extracted by $\mathrm{Et}_{2} \mathrm{O}$. The organic layer was dried over $\mathrm{MgSO}_{4}$ and concentrated in vacuo. The residue was purified by column chromatography $\left(\mathrm{CH}_{2} \mathrm{Cl}_{2}-\mathrm{MeOH}=20: 1\right)$ to give compound $16(101 \mathrm{mg}, 71 \%)$ as white amorphous.

IR $\left(\mathrm{CHCl}_{3}\right) \mathrm{cm}^{-1}: 3688,3327,2928,1719,1634,1616,1578$; $[\alpha]_{\mathrm{D}}^{20}-13.8\left(c=0.87, \mathrm{CHCl}_{3}\right) ;{ }^{1} \mathrm{H}-\mathrm{NMR}\left(\mathrm{CDCl}_{3}, 400 \mathrm{MHz}\right) \delta$ : $8.24(\mathrm{t}, 1 \mathrm{H}, J=4.4 \mathrm{~Hz}), 3.66(\mathrm{~s}, 3 \mathrm{H}), 3.27(\mathrm{~m}, 2 \mathrm{H}), 2.22(\mathrm{~d}$, $2 \mathrm{H}, J=7.1 \mathrm{~Hz}), 1.83-0.72(\mathrm{~m}, 23 \mathrm{H}), 1.48(\mathrm{~s}, 18 \mathrm{H}), 1.02(\mathrm{~s}, 3 \mathrm{H})$, $0.72(\mathrm{~s}, 3 \mathrm{H}) ;{ }^{13} \mathrm{C}-\mathrm{NMR}\left(\mathrm{CDCl}_{3}, 100 \mathrm{MHz}\right) \delta: 178.8,178.2$, 163.3, 155.8, 153.0, 82.9, 79.1, 53.4, 51.7, 47.9, 47.2, 46.0, 41.8, $41.4,38.1,37.8,37.1,36.0,35.1,35.0,32.0,30.0,29.4,28.9$, 28.5, 28.4, 28.1, 19.8, 15.3, 12.4; HR-MS (FAB) Calcd for $\mathrm{C}_{34} \mathrm{H}_{58} \mathrm{~N}_{3} \mathrm{O}_{8} \mathrm{~m} / \mathrm{z}\left[\mathrm{MH}^{+}\right]:$635.4146. Found 636.4224;

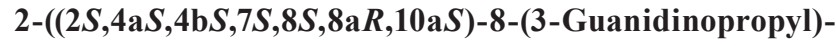


7-(methoxycarbonyl)-4a,7-dimethyltetradecahydrophenanthren-2-yl)acetic Acid (3b) To a solution of $16(50 \mathrm{mg}$, $0.08 \mathrm{mmol})$ in $\mathrm{CH}_{2} \mathrm{Cl}_{2}(786 \mu \mathrm{L})$ was added TFA $(606 \mu \mathrm{L}$, d $1.48,7.86 \mathrm{mmol})$ at $0^{\circ} \mathrm{C}$, and the mixture was stirred at r.t. for $5 \mathrm{~h}$. The reaction mixture was concentrated to give a crude guanidine $3 \mathbf{b}$ (34 mg, quant, 69\% purity) as a colorless oil.

IR $\left(\mathrm{CHCl}_{3}\right) \mathrm{cm}^{-1}: 2952,2924,1710,1678,1199 ;[\alpha]_{\mathrm{D}}^{27}-56.0$ $(c=0.03, \mathrm{EtOH}) ;{ }^{1} \mathrm{H}-\mathrm{NMR}\left(\mathrm{CDCl}_{3}, 400 \mathrm{MHz}\right) \delta: 3.65(\mathrm{~s}, 3 \mathrm{H})$, $3.07(\mathrm{t}, 2 \mathrm{H}, J=6.7 \mathrm{~Hz}), 2.17(\mathrm{~d}, 2 \mathrm{H}, J=7.1 \mathrm{~Hz}), 1.94(\mathrm{dd}, 1 \mathrm{H}$, $J=12.5,2.8 \mathrm{~Hz}), 1.84-0.60(\mathrm{~m}, 22 \mathrm{H}), 1.11$ (s, 3H), 0.78 (s, 3H); ${ }^{13} \mathrm{C}-\mathrm{NMR}\left(\mathrm{CD}_{3} \mathrm{OD}, 100 \mathrm{MHz}\right) \delta: 180.4,176.6,158.3,55.0,52.3$, 49.1, 48.6, 47.4, 42.75, 42.69, 39.4, 39.2, 38.4, 37.1, 36.5, 36.2, $33.3,31.0,30.3,30.1,29.5,20.8,16.0,12.8$; HR-MS (FAB) Calcd for $\mathrm{C}_{24} \mathrm{H}_{42} \mathrm{~N}_{3} \mathrm{O}_{4} \mathrm{~m} / z\left[\mathrm{M}+\mathrm{H}^{+}\right]$: 436.3186. Found 436.3181.

Methyl 2-((4aS,8aS)-8a-Methylhexahydro-2H-spiro[naphthalene-1,2'-[1,3]dioxolan]-6(5H)-ylidene)acetate (18a) Under a nitrogen atmosphere, to a suspension of $t$-BuOK $(3.0 \mathrm{~g}, 27 \mathrm{mmol})$ in anhydrous DMF $(22 \mathrm{~mL})$ was added methyl diethylphosphonoacetate $(4.9 \mathrm{~mL}, \mathrm{~d} 1.15,27 \mathrm{mmol})$ at r.t. and stirred for $1.5 \mathrm{~h}$. The mixture was cooled to $0^{\circ} \mathrm{C}$ and the solution of $17(2.0 \mathrm{~g}, 8.9 \mathrm{mmol})$ in anhydrous DMF $(23 \mathrm{~mL})$ was added, and the resulting mixture was stirred for $12.5 \mathrm{~h}$. The reaction mixture was poured into water and extracted with $\mathrm{Et}_{2} \mathrm{O}$. The combined extracts was washed with brine, dried over $\mathrm{MgSO}_{4}$ and concentrated under the reduced pressure. The residue was purified by column chromatography (AcOEt- $n$ hexane $=1: 4)$ to give compound 18a $(2.6 \mathrm{~g}, 98 \%)$ as a colorless oil.

IR $\left(\mathrm{CHCl}_{3}\right) \mathrm{cm}^{-1}: 2949,1707,1165 ;[\alpha]_{\mathrm{D}}^{26}+0.88(c=0.90$ EtOH); ${ }^{1} \mathrm{H}-\mathrm{NMR}\left(\mathrm{CDCl}_{3}, 400 \mathrm{MHz}, E: Z=1: 1\right) \delta: 5.59(1 / 2 \mathrm{H}$, s), $5.58(1 / 2 \mathrm{H}, \mathrm{s}), 3.95-3.81(4 \mathrm{H}, \mathrm{m}), 3.77(1 / 2 \mathrm{H}, \mathrm{d}, J=14.4 \mathrm{~Hz})$, $3.67(3 / 2 \mathrm{H}, \mathrm{s}), 3.66(3 / 2 \mathrm{H}, \mathrm{s}), 3.56(1 / 2 \mathrm{H}, \mathrm{d}, J=13.6 \mathrm{~Hz})$, 2.43-1.21 (12H, m), $1.10(3 \mathrm{H}, \mathrm{s}) ;{ }^{13} \mathrm{C}-\mathrm{NMR}\left(\mathrm{CDCl}_{3}, 100 \mathrm{MHz}\right.$, $E: Z=1: 1) \delta: 167.2,167.1,163.0,162.9,112.7,112.54,112.50$, $112.4,65.1,65.0,64.93,64.87,50.67,50.66,42.8,42.3,42.2$, $42.0,39.6,33.1,31.6,31.4,31.0,30.5,30.4,27.9,27.7,24.8$, 22.80, 22.77, 13.5, 13.3; HR-MS (EI) Calcd for $\mathrm{C}_{16} \mathrm{H}_{24} \mathrm{O}_{4} \mathrm{~m} / \mathrm{z}$ $\left[\mathrm{M}^{+}\right]$: 280.1675. Found 280.1672 .

2 - ( $(4$ a $S, 8$ a $S)-8$ a-Methylhexahyd ro-2 $H$-spiro[naphthalene-1,2'-[1,3]dioxolan]-6(5H)-ylidene)acetic Acid (18b) To a suspension of $\mathbf{1 8 a}(2.5 \mathrm{~g}, 8.6 \mathrm{mmol})$ in $1: 1 \mathrm{EtOH} / \mathrm{H}_{2} \mathrm{O}$ $(86 \mathrm{~mL})$ was added $\mathrm{KOH}(4.8 \mathrm{~g}, 86 \mathrm{mmol})$, and the mixture was heated at $90^{\circ} \mathrm{C}$ for $0.5 \mathrm{~h}$. The reaction mixture was concentrated and neutralized with $3 \mathrm{M} \mathrm{HCl}$ on an ice bath. The mixture was extracted with $\mathrm{CH}_{2} \mathrm{Cl}_{2}$, and the combined organic layer was dried over $\mathrm{MgSO}_{4}$. The concentrated residue was purified by column chromatography $\left(\mathrm{CH}_{2} \mathrm{Cl}_{2}-\mathrm{MeOH}=20: 1\right)$ to give $\alpha, \beta$-unsaturated carboxylic acid $\mathbf{1 8 b}(2.1 \mathrm{~g}, 93 \%)$ as a white amorphous.

IR $\left(\mathrm{CHCl}_{3}\right) \mathrm{cm}^{-1}: 2933,1685,1631 ;[\alpha]_{\mathrm{D}}^{26}-12.7(c=0.06$, EtOH); ${ }^{1} \mathrm{H}-\mathrm{NMR}\left(\mathrm{CDCl}_{3}, 400 \mathrm{MHz}, E: Z=1: 1\right) \delta: 11.8(1 \mathrm{H}$, brs), $5.61(1 / 2 \mathrm{H}, \mathrm{s}), 5.60(1 / 2 \mathrm{H}, \mathrm{s}), 3.98-3.82(4 \mathrm{H}, \mathrm{m}), 3.77$ $(1 / 2 \mathrm{H}, \mathrm{d}, J=14.8 \mathrm{~Hz}), 3.55(1 / 2 \mathrm{H}, \mathrm{d}, J=13.2 \mathrm{~Hz}), 2.35(1 / 2 \mathrm{H}$, $\mathrm{dt}, J=4.8,13.6 \mathrm{~Hz}), 2.35-2.10(\mathrm{~m}, 1 \mathrm{H}), 2.05-1.90(\mathrm{~m}, 1 \mathrm{H})$, 1.87-1.45 (m, 15/2H), 1.41-1.17 (m, 2H), 1.10 (s, 3/2H), 1.09 (s, $3 / 2 \mathrm{H}) ;{ }^{13} \mathrm{C}-\mathrm{NMR}\left(\mathrm{CDCl}_{3}, 100 \mathrm{MHz}, E: Z=1: 1\right) \delta: 172.3,172.2$, $165.8,165.6,112.8,112.6(2 \mathrm{C}), 112.5,65.14,65.08,65.0,64.9$, $42.9,42.3,42.2,42.1,39.9,33.3,31.6(2 \mathrm{C}), 31.1,30.5,30.4$, 27.9, 27.7, 25.1, 22.80, 22.77, 13.5, 13.4; HR-MS (EI) Calcd for $\mathrm{C}_{15} \mathrm{H}_{22} \mathrm{O}_{4} \mathrm{~m} / \mathrm{z}\left[\mathrm{M}^{+}\right]:$266.1518. Found 266.1517.

Methyl 2-((2S,4aS,8aS)-4a-Methyl-5-oxodecahydronaph- thalen-2-yl)acetate (19) Under a nitrogen atmosphere, a lithium wire $(0.5 \mathrm{~g}, 68 \mathrm{mmol})$ was added to liquid ammonia $(96 \mathrm{~mL})$ at $-78^{\circ} \mathrm{C}$. To this mixture was added a solution of 18b $(1.8 \mathrm{~g}, 6.8 \mathrm{mmol})$ in THF $(45 \mathrm{~mL})$, and the resulting mixture was stirred for $3 \mathrm{~h}$. After the substrate disappearance was monitoring by TLC, solid $\mathrm{NH}_{4} \mathrm{Cl}$ was added until the mixture turned white suspension. The mixture was allowed to r.t. and the liquid ammonia was evaporated through the night. The residue was suspended with $\mathrm{CH}_{2} \mathrm{Cl}_{2}$ and filtrated. To the concentrated residue in THF $(68 \mathrm{~mL})$ was added $1.5 \mathrm{M} \mathrm{HCl}$ $(0.11 \mathrm{~L})$ using a dropping funnel at $0^{\circ} \mathrm{C}$, and the mixture and stirred for $1 \mathrm{~h}$ at r.t. The reaction mixture was extracted with $\mathrm{CH}_{2} \mathrm{Cl}_{2}$ and dried over $\mathrm{MgSO}_{4}$. To the concentrated residue was added $\mathrm{MeI}(6.9 \mathrm{~mL}, 68 \mathrm{mmol})$ and $\mathrm{K}_{2} \mathrm{CO}_{3}(1.9 \mathrm{~g}, 14 \mathrm{mmol})$, and then the mixture was stirred at r.t. overnight. The reaction was concentrated, diluted with $\mathrm{Et}_{2} \mathrm{O}$ and washed with $\mathrm{H}_{2} \mathrm{O}$. The organic layer was dried over $\mathrm{MgSO}_{4}$ and concentrated. The crude material was purified by column chromatography (AcOEt $-n$-hexane $=1: 2$ ) to give compound $19(1.5 \mathrm{~g}, 91 \%$, in 3 steps) as a colorless oil.

IR $\left(\mathrm{CHCl}_{3}\right) \mathrm{cm}^{-1}: 3010,2933,2862,1730,1699 ;[\alpha]_{\mathrm{D}}^{20}-7.9$ $(c=0.15, \mathrm{EtOH}) ;{ }^{1} \mathrm{H}-\mathrm{NMR}\left(\mathrm{CDCl}_{3}, 300 \mathrm{MHz}\right) \delta: 3.67(3 \mathrm{H}$, s), 2.66-2.63 $(1 \mathrm{H}, \mathrm{m}), 2.28-2.17(3 \mathrm{H}, \mathrm{m}), 2.08-1.96(1 \mathrm{H}, \mathrm{m})$, 1.84-1.41 (9H, m), 1.26-1.12 (2H, m), 1.09 (3H, s); ${ }^{13} \mathrm{C}-\mathrm{NMR}$ $\left(\mathrm{CDCl}_{3}, 100 \mathrm{MHz}\right) \delta: 215.9,173.1,51.3,47.8,45.2,41.3,37.3$, 34.6, 33.8, 32.1, 27.7, 27.3, 26.0, 15.5; HR-MS (EI) Calcd for $\mathrm{C}_{14} \mathrm{H}_{22} \mathrm{O}_{3} m / z\left[\mathrm{M}^{+}\right]: 238.1569$. Found 238.1562.

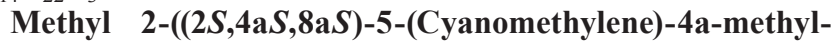
decahydronaphthalen-2-yl)acetate (20) To a suspension of $\mathrm{KO}^{t} \mathrm{Bu}(3.6 \mathrm{~g}, 32 \mathrm{mmol})$ in DMF $(30 \mathrm{~mL})$ was added diethyl cyanomethylphosphonate $(5.0 \mathrm{~mL}, \mathrm{~d} 1.13,32 \mathrm{mmol})$ under a nitrogen atmosphere, and the mixture was stirred at $0^{\circ} \mathrm{C}$ for $1 \mathrm{~h}$. To the solution was added $19(2.5 \mathrm{~g}, 11 \mathrm{mmol})$ in anhydrous DMF $(25 \mathrm{~mL})$ and the resulting mixture was stirred at $90^{\circ} \mathrm{C}$ for $1 \mathrm{~h}$. The reaction mixture was added $\mathrm{H}_{2} \mathrm{O}$ and extracted with $\mathrm{Et}_{2} \mathrm{O}$. The combined extracts was dried over $\mathrm{MgSO}_{4}$ and concentrated. The residue was purified by column chromatography $($ AcOEt $-n$-hexane $=1: 5)$ to give compound $20(2.6 \mathrm{~g}$, $95 \%)$ as a colorless oil.

IR $\left(\mathrm{CHCl}_{3}\right) \quad \mathrm{cm}^{-1}:$ 2983, 2929, 2216, 1730; $[\alpha]_{\mathrm{D}}^{25}-71.9$ $(c=0.46, \mathrm{EtOH}) ;{ }^{1} \mathrm{H}-\mathrm{NMR}\left(\mathrm{CDCl}_{3}, 400 \mathrm{MHz}\right) \delta: 5.03(1 \mathrm{H}, \mathrm{d}$, $J=1.6 \mathrm{~Hz}), 3.67(3 \mathrm{H}, \mathrm{s}), 2.94-2.78(1 \mathrm{H}, \mathrm{m}), 2.42-2.30(1 \mathrm{H}$, m), 2.29-2.10 (2H, m), 1.98-1.67 (3H, m), 1.66-1.57 (1H, m), $1.51-1.03(8 \mathrm{H}, \mathrm{m}), 1.01(3 \mathrm{H}, \mathrm{s}) ;{ }^{13} \mathrm{C}-\mathrm{NMR}\left(\mathrm{CDCl}_{3}, 100 \mathrm{MHz}\right)$ $\delta: 175.9,173.0,117.7,90.2,51.3,45.2,41.2,40.6,35.5,34.58$, 34.55, 30.1, 28.2, 28.0, 27.0, 16.9; HR-MS (EI) Calcd for $\mathrm{C}_{16} \mathrm{H}_{23} \mathrm{NO}_{2} m / z\left[\mathrm{M}^{+}\right]$: 261.1729. Found 261.1725.

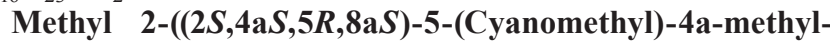
decahydronaphthalen-2-yl)acetate (21) Under a hydrogen balloon atmosphere, a suspension of compound $\mathbf{2 0}$ (12 mg, $0.046 \mathrm{mmol}), 10 \% \mathrm{Pd} / \mathrm{C}(2.0 \mathrm{mg})$ in $\mathrm{EtOH}(1.4 \mathrm{~mL})$ was stirred at r.t. for $1.5 \mathrm{~h}$. The reaction mixture was filtered through a Celite pad and concentrated. The residue was purified by column chromatography (AcOEt $-n$-hexane $=1: 5$ ) to give compound 21 (12 mg, quant, $\beta: \alpha=14: 1$ ) as a colorless oil.

IR $\left(\mathrm{CHCl}_{3}\right) \mathrm{cm}^{-1}: 2927,2858,2247,1730 ;[\alpha]_{\mathrm{D}}^{23}+100$ $(c=0.004, \mathrm{EtOH}) ;{ }^{1} \mathrm{H}-\mathrm{NMR}\left(\mathrm{CDCl}_{3}, 400 \mathrm{MHz}\right) \delta: 3.66(3 \mathrm{H}$, s), $2.63-2.35(1 \mathrm{H}, \mathrm{m}), 2.21(2 \mathrm{H}, \mathrm{d}, J=7.2 \mathrm{~Hz}), 2.00(1 \mathrm{H}$, dd, $J=16.4,10.4 \mathrm{~Hz}), 1.90-1.71(3 \mathrm{H}, \mathrm{m}), 1.67-1.56(2 \mathrm{H}, \mathrm{m})$, $1.53-0.96(10 \mathrm{H}, \mathrm{m}), 0.72(3 \mathrm{H}, \mathrm{s}) ;{ }^{13} \mathrm{C}-\mathrm{NMR}\left(\mathrm{CDCl}_{3}, 100 \mathrm{MHz}\right)$ $\delta$ : 173.3, 120.1, 51.4, 45.7, 45.6, 41.5, 38.1, 36.3, 35.0, 34.8, 
28.5, 28.2, 27.8, 25.9, 18.3, 10.9; HR-MS (EI) Calcd for $\mathrm{C}_{16} \mathrm{H}_{25} \mathrm{NO}_{2} \mathrm{~m} / \mathrm{z}\left[\mathrm{M}^{+}\right]: 263.1885$. Found 263.1881.

Methyl 2-((2S,4aS,5R,8aS)-5-(2-((Z)-2,3-Bis(tert-butoxycarbonyl)guanidino)ethyl)-4a-methyldecahydronaphthalen2-yl)acetate (22) Under a hydrogen atmosphere (balloon), a suspension of compound $21(0.11 \mathrm{~g}, 0.45 \mathrm{mmol})$ and $\mathrm{PtO}_{2}$ $(20 \mathrm{mg})$ in $10 \% \mathrm{HCl}-\mathrm{MeOH}(12 \mathrm{~mL})$ was stirred at r.t. for $140 \mathrm{~min}$. The reaction mixture was filtered through a Celite pad and concentrated. The residue was dissolved in DMF $(3.9 \mathrm{~mL})$, and $\mathrm{Et}_{3} \mathrm{~N}(0.16 \mathrm{~mL}, \mathrm{~d} 0.73,1.2 \mathrm{mmol})$ and $N, N^{\prime}-$ bis(tert-butoxycarbonyl)- $1 H$-pyrazole-1-carboxamidine $(0.15 \mathrm{~g}$, $0.47 \mathrm{mmol}$ ) was added. After $1 \mathrm{~h}$ stirring, the reaction mixture was added $\mathrm{H}_{2} \mathrm{O}$, extracted with $\mathrm{Et}_{2} \mathrm{O}$, and dried over $\mathrm{MgSO}_{4}$. The concentrated residue was purified by column chromatography (AcOEt- $n$-hexane $=1: 5)$ to give compound $22(114 \mathrm{mg}$, $83 \%, 2$ steps) as a colorless amorphous.

IR $\left(\mathrm{CHCl}_{3}\right) \mathrm{cm}^{-1}: 2981,2926,2856,1720,1633 ;[\alpha]_{\mathrm{D}}^{26}+2.2$ $(c=0.09, \mathrm{EtOH}) ;{ }^{1} \mathrm{H}-\mathrm{NMR}\left(\mathrm{CDCl}_{3}, 400 \mathrm{MHz}\right) \delta: 11.5(1 \mathrm{H}$, br s$)$, $8.25(1 \mathrm{H}$, brs $), 3.66(3 \mathrm{H}, \mathrm{s}), 3.62-3.22(2 \mathrm{H}, \mathrm{m}), 2.20(2 \mathrm{H}, \mathrm{d}$, $J=6.8 \mathrm{~Hz}), 1.99-1.38(10 \mathrm{H}, \mathrm{m}), 1.26(9 \mathrm{H}, \mathrm{s}), 1.22-0.70(13 \mathrm{H}$, $\mathrm{m}), 0.53(3 \mathrm{H}, \mathrm{s}) ;{ }^{13} \mathrm{C}-\mathrm{NMR}\left(\mathrm{CDCl}_{3}, 100 \mathrm{MHz}\right) \delta: 173.4,163.6$, $156.0,153.3,82.9,79.1,51.3,46.3,45.9,41.7,40.2,37.9,36.3$, 35.2, 29.6, 28.9, 28.8, 28.4, 28.3, 28.0, 27.7, 26.3, 11.1; HR-MS (FAB) Calcd for $\mathrm{C}_{27} \mathrm{H}_{47} \mathrm{~N}_{3} \mathrm{O}_{6} \mathrm{~m} / \mathrm{z}\left[\mathrm{M}^{+}\right]$: 510.3543. Found 510.3543.

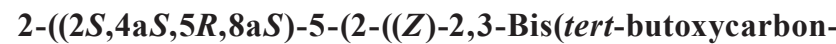
yl)guanidino)ethyl)-4a-methyldecahydronaphthalen-2yl)acetic Acid (24) To a solution of $22(1.5 \mathrm{~g}, 3.1 \mathrm{mmol}$, $\beta: \alpha=14: 1)$ in $\mathrm{MeOH}-\mathrm{THF}(62 \mathrm{~mL}, 1: 1)$ was added $10 \%$ aqueous $\mathrm{LiOH}(15 \mathrm{~mL}, 0.2 \mathrm{M})$ and stirred at r.t. for $4 \mathrm{~h}$. The mixture was concentrated in vacuo and diluted with $\mathrm{CH}_{2} \mathrm{Cl}_{2}$. The solution was neutralized with dil $\mathrm{HCl}$ and aqueous layer was extracted with $\mathrm{CH}_{2} \mathrm{Cl}_{2}$ and dried over $\mathrm{MgSO}_{4}$. The concentrated residue was purified by column chromatography $\left(\mathrm{CH}_{2} \mathrm{Cl}_{2}-\mathrm{MeOH}=10: 1\right)$ to give compound $23(1.2 \mathrm{~g}, 75 \%$, $\beta: \alpha=14: 1)$ as a white solid. This product was recrystallized from $\mathrm{Et}_{2} \mathrm{O}$ to give $\beta$-isomer 24 as a white powder $(0.20 \mathrm{~g}$, $13 \%)$.

mp $108-112^{\circ} \mathrm{C}$ (AcOEt- $n$-hexane); IR $\left(\mathrm{CHCl}_{3}\right) \mathrm{cm}^{-1}: 3332$, 2926, 1720, 1641, 1394; $[\alpha]_{\mathrm{D}}^{21}-6.6\left(c=0.09\right.$, EtOH); ${ }^{1} \mathrm{H}-\mathrm{NMR}$ $\left(\mathrm{CDCl}_{3}, 400 \mathrm{MHz}\right) \delta$ : $8.24(1 \mathrm{H}$, brs $), 3.49-3.38(1 \mathrm{H}, \mathrm{m})$, $3.33-3.24(1 \mathrm{H}, \mathrm{m}), 2.24(2 \mathrm{H}, \mathrm{d}, J=6.8 \mathrm{~Hz}), 1.89-1.58(8 \mathrm{H}$, m), $1.50(18 \mathrm{H}, \mathrm{s}), 1.43-0.92(11 \mathrm{H}, \mathrm{m}), 0.69(3 \mathrm{H}, \mathrm{s}) ;{ }^{13} \mathrm{C}-\mathrm{NMR}$ $\left(\mathrm{CDCl}_{3}, 100 \mathrm{MHz}\right) \delta: 178.7,163.5,156.0,153.7,83.0,79.2$, 46.3, 41.7, 40.3, 37.9, 36.3, 36.1, 35.1, 28.89, 28.85, 28.4, 28.3, 28.0, 27.6, 26.3, 11.1; HR-MS (FAB) Calcd for $\mathrm{C}_{26} \mathrm{H}_{46} \mathrm{~N}_{3} \mathrm{O}_{6} m / z$ $\left[\mathrm{MH}^{+}\right]:$496.3387. Found 496.3384.

2-((2S,4a $S, 5 R, 8 \mathrm{a} S)-5-(2-G u a n i d i n o e t h y l)-4 a-m e t h y l d e c a-$ hydronaphthalen-2-yl)acetic Acid (3c) To a solution of $\mathbf{2 4}$ $(39 \mathrm{mg}, 0.080 \mathrm{mmol})$ was added $\mathrm{HCl}-\mathrm{AcOEt}(0.80 \mathrm{~mL}, 0.4 \mathrm{M})$ at $0^{\circ} \mathrm{C}$ and stirred at r.t. for $31 \mathrm{~h}$. The mixture was concentrated in vacuo to give compound $3 \mathbf{c}$ ( $24 \mathrm{mg}$, quant, $70 \%$ purity) as a white amorphous.

IR $\left(\mathrm{CHCl}_{3}\right) \mathrm{cm}^{-1}: 3435,3417,1633,1261,1095,1022,802$; $[\alpha]_{\mathrm{D}}^{23}+22.7(c=0.22, \mathrm{EtOH}) ;{ }^{1} \mathrm{H}-\mathrm{NMR}\left(\mathrm{CDCl}_{3}, 300 \mathrm{MHz}\right) \delta$ : 7.48-7.35 (1H, m), 3.24-2.82 (2H, m), $2.10(2 \mathrm{H}, \mathrm{d}, J=7.2 \mathrm{~Hz})$, $1.90-0.83(20 \mathrm{H}, \mathrm{m}), 0.66(3 \mathrm{H}, \mathrm{s}) ;{ }^{13} \mathrm{C}-\mathrm{NMR}\left(\mathrm{CDCl}_{3}, 125 \mathrm{MHz}\right)$ $\delta: 173.6,156.6,53.5,52.3,49.4,37.5,35.9,34.7,28.5,28.3$, 27.8, 27.6, 26.9, 25.9, 11.0, 0.05; HR-MS (FAB) Calcd for $\mathrm{C}_{16} \mathrm{H}_{30} \mathrm{~N}_{3} \mathrm{O}_{2} \mathrm{~m} / \mathrm{z}\left[\mathrm{MH}^{+}\right]:$296.2338. Found 296.2335.

(3aS,7a $S)$-7a-Methylhexahydrospiro[indene-1, $2^{\prime}-[1,3]-$
dioxolan]-5(4H)-one (25) Under a nitrogen atmosphere, a lithium wire $(0.16 \mathrm{~g}, 23.0 \mathrm{mmol})$ was added to liquid ammonia $(30 \mathrm{~mL})$ at $-78^{\circ} \mathrm{C}$. To the reaction mixture was added the solution of acetal $(1.5 \mathrm{~g}, 7.2 \mathrm{mmol})$ in THF $(18 \mathrm{~mL})$, and the resulting mixture was stirred for $100 \mathrm{~min}$. After the substrate disappearance was monitored by TLC, solid $\mathrm{NH}_{4} \mathrm{Cl}$ was added until the mixture turned white suspension. The mixture was allowed to r.t. and the liquid ammonia was evaporated through the night. The residue was suspended with $\mathrm{CH}_{2} \mathrm{Cl}_{2}$ and filtrated. The concentrated residue was purified by column chromatography (AcOEt- $n$-hexane $=1: 4)$ to give compound $25(1.0 \mathrm{~g}$, $70 \%$ ) as a colorless oil.

IR $\left(\mathrm{CHCl}_{3}\right) \mathrm{cm}^{-1}: 2956,1705 ;[\alpha]_{\mathrm{D}}^{22}+58.8(c=0.17, \mathrm{EtOH})$; ${ }^{1} \mathrm{H}-\mathrm{NMR}\left(\mathrm{CDCl}_{3}, 400 \mathrm{MHz}\right) \delta: 3.97-3.87$ (4H, m), 2.52-2.19 $(5 \mathrm{H}, \mathrm{m}), 2.02-1.78(4 \mathrm{H}, \mathrm{m}), 1.72-1.66(1 \mathrm{H}, \mathrm{m}), 1.42-1.30(1 \mathrm{H}$, $\mathrm{m}), 1.16(3 \mathrm{H}, \mathrm{s}) ;{ }^{13} \mathrm{C}-\mathrm{NMR}\left(\mathrm{CDCl}_{3}, 100 \mathrm{MHz}\right) \delta: 213.0,119.4$, 65.2, 64.4, 44.3, 44.1, 42.2, 37.1, 32.9, 29.4, 25.7, 18.4; HR-MS (EI) Calcd for $\mathrm{C}_{12} \mathrm{H}_{18} \mathrm{O}_{3} \mathrm{~m} / z\left[\mathrm{M}^{+}\right]$: 210.1256. Found 210.1257 .

Methyl 2-((3aS,7aS)-7a-Methylhexahydrospiro[indene1,2'-[1,3]dioxolan]-5(4H)-ylidene)acetate To a suspension of $\mathrm{KO}^{t} \mathrm{Bu}(0.11 \mathrm{~g}, 1.1 \mathrm{mmol})$ in $\mathrm{DMF}(0.75 \mathrm{~mL})$ was added methyl 2-(diethoxyphosphoryl)acetate $(0.19 \mathrm{~mL}, \mathrm{~d} \quad 1.15$, $1.1 \mathrm{mmol}$ ), and the mixture was stirred at $0^{\circ} \mathrm{C}$ for $10 \mathrm{~min}$ under a nitrogen atmosphere. To the mixture was added compound 25 (74 mg, $0.35 \mathrm{mmol})$ in anhydrous DMF $(1.0 \mathrm{~mL})$ and the resulting mixture was stirred at r.t. for $30 \mathrm{~h}$. The reaction mixture was added $\mathrm{H}_{2} \mathrm{O}$ and extracted with $\mathrm{Et}_{2} \mathrm{O}$. The combined extract was dried over $\mathrm{MgSO}_{4}$ and concentrated. The residue was purified by column chromatography (AcOEt- $n$ hexane $=1: 4)$ to give $\alpha, \beta$-unsaturated ester $(90 \mathrm{mg}, 97 \%)$ as a colorless oil.

IR $\left(\mathrm{CHCl}_{3}\right) \mathrm{cm}^{-1}: 3012,2949,2879,1708,1649 ;[\alpha]_{\mathrm{D}}^{21}+65.5$ $(c=0.07, \mathrm{EtOH}) ;{ }^{1} \mathrm{H}-\mathrm{NMR}\left(\mathrm{CDCl}_{3}, 400 \mathrm{MHz}, E: Z=1: 1\right) \delta$ : $5.76(1 / 2 \mathrm{H}, \mathrm{s}), 5.64(1 / 2 \mathrm{H}, \mathrm{s}), 3.95-3.81(4 \mathrm{H}, \mathrm{m}), 3.69(3 / 2 \mathrm{H}$, s), $3.68(3 / 2 \mathrm{H}, \mathrm{s}), 3.62-3.50(1 \mathrm{H}, \mathrm{m}), 2.47-1.19(10 \mathrm{H}, \mathrm{m})$, $1.06(3 / 2 \mathrm{H}, \mathrm{s}), 1.05(3 / 2 \mathrm{H}, \mathrm{s}) ;{ }^{13} \mathrm{C}-\mathrm{NMR}\left(\mathrm{CDCl}_{3}, 100 \mathrm{MHz}\right.$, $E: Z=1: 1) \delta: 167.0,166.7,161.7,161.6,120.0$ (2C), 115.0, 114.6, 65.2 (2C), 64.2, 64.1, 50.7 (2C), 44.7, 44.6, 43.9, 43.8, 37.2, $33.1,32.7,32.6,31.3,29.8,28.7,25.1,23.9,23.5,17.6,16.9$; HR-MS (EI) Calcd for $\mathrm{C}_{15} \mathrm{H}_{22} \mathrm{O}_{4} \mathrm{~m} / z\left[\mathrm{M}^{+}\right]$: 266.1518. Found 266.1516 .

2-((3aS,7a $S)-7$ a-Methylhexahydrospiro[indene-1,2' [1,3]dioxolan]-5(4H)-ylidene)acetic Acid (26) To a solution of $\alpha, \beta$-unsaturated ester $(57 \mathrm{mg}, 0.21 \mathrm{mmol})$ in $1: 1 \mathrm{EtOH} / \mathrm{H}_{2} \mathrm{O}$ $(2.0 \mathrm{~mL})$ was added powdered $\mathrm{KOH}(0.12 \mathrm{~g}, 2.1 \mathrm{mmol})$ and the mixture was heated at $90^{\circ} \mathrm{C}$ for $15 \mathrm{~min}$. The reaction mixture was concentrated and neutralized with $10 \% \mathrm{HCl}$ on an ice bath. The mixture was extracted with $\mathrm{CH}_{2} \mathrm{Cl}_{2}$ and the combined organic layer was dried over $\mathrm{MgSO}_{4}$. The concentrated residue was purified by column chromatography (AcOEt $-n$ hexane $=1: 3)$ to give compound $26(38 \mathrm{mg}, 71 \%)$ as a white amorphous.

IR $\left(\mathrm{CHCl}_{3}\right) \quad \mathrm{cm}^{-1}:$ 3016, 2949, 2879, 1687; $[\alpha]_{\mathrm{D}}^{25}+100$ $(c=0.02, \mathrm{EtOH}) ;{ }^{1} \mathrm{H}-\mathrm{NMR}\left(\mathrm{CDCl}_{3}, 400 \mathrm{MHz}, E: Z=1: 1\right) \delta$ : $5.78(1 / 2 \mathrm{H}, \mathrm{s}), 5.67(1 / 2 \mathrm{H}, \mathrm{s}), 3.95-3.79(4 \mathrm{H}, \mathrm{m}), 3.55(1 \mathrm{H}, \mathrm{d}$, $J=16.0 \mathrm{~Hz}), 2.49-1.10(11 \mathrm{H}, \mathrm{m}), 1.06(3 / 2 \mathrm{H}, \mathrm{s}), 1.05(3 / 2 \mathrm{H}, \mathrm{s})$; ${ }^{13} \mathrm{C}-\mathrm{NMR}\left(\mathrm{CDCl}_{3}, 100 \mathrm{MHz}, E: Z=1: 1\right) \delta: 165.6,165.5,164.8$, 164.6, 120.1, 120.1, 114.8, 114.3, 65.3, 64.3, 64.2, 44.7, 44.7, $44.1,44.0,37.6,33.5,32.8,32.7,31.3,29.8,29.1,25.4,24.1$, 23.7, 17.9, 17.0; HR-MS (EI) Calcd for $\mathrm{C}_{14} \mathrm{H}_{20} \mathrm{O}_{4} \mathrm{~m} / z\left[\mathrm{M}^{+}\right]$: 252.1362. Found 252.1356. 
Methyl 2-((3aS,5S,7aS)-7a-Methyl-1-oxooctahydro-1Hinden-5-yl)acetate (27) Under a nitrogen atmosphere, a lithium wire $(0.74 \mathrm{~g}, 0.10 \mathrm{~mol})$ was added to liquid ammonia $(150 \mathrm{~mL})$ at $-78^{\circ} \mathrm{C}$. To the reaction mixture was added the solution of $26(2.7 \mathrm{~g}, 11 \mathrm{mmol})$ in THF $(100 \mathrm{~mL})$, and the mixture was stirred for $25 \mathrm{~min}$ at r.t. After the substrate disappearance was monitored by TLC, solid $\mathrm{NH}_{4} \mathrm{Cl}$ was added until the mixture turned white suspension. The mixture was allowed to r.t. and the liquid ammonia was evaporated through the night. The residue was suspended with $\mathrm{CH}_{2} \mathrm{Cl}_{2}$ and filtrated. To the concentrated residue in THF $(100 \mathrm{~mL})$ was added $1.5 \mathrm{M} \mathrm{HCl}$ $(40 \mathrm{~mL})$ using a dropping funnel at $0^{\circ} \mathrm{C}$, and the mixture and stirred for $1.5 \mathrm{~h}$ at r.t. The reaction mixture was extracted with $\mathrm{CH}_{2} \mathrm{Cl}_{2}$ and dried over $\mathrm{MgSO}_{4}$. To the concentrated residue was dissolved in acetone $(100 \mathrm{~mL})$, and $\mathrm{MeI}(11 \mathrm{~mL}, 0.10 \mathrm{~mol})$ and $\mathrm{K}_{2} \mathrm{CO}_{3}(6.0 \mathrm{~g}, 43 \mathrm{mmol})$ were added, and then the mixture was stirred for overnight. The reaction was concentrated, diluted with $\mathrm{Et}_{2} \mathrm{O}$ and washed with $\mathrm{H}_{2} \mathrm{O}$. The organic layer was dried over $\mathrm{MgSO}_{4}$ and concentrated. The crude material was purified by column chromatography (AcOEt- $n$-hexane $=1: 2$ ) to give compound 27 (2.4 g, 98\%, 3 steps) as a colorless oil.

IR $\left(\mathrm{CHCl}_{3}\right) \mathrm{cm}^{-1}: 2953,2929,2358,2339,1730 ;[\alpha]_{\mathrm{D}}^{20}+35.6$ $(c=0.03, \mathrm{EtOH}) ;{ }^{1} \mathrm{H}-\mathrm{NMR}\left(\mathrm{CDCl}_{3}, 400 \mathrm{MHz}\right) \delta: 3.68(3 \mathrm{H}$, s), $2.54-2.38(1 \mathrm{H}, \mathrm{m}), 2.32-1.80(7 \mathrm{H}, \mathrm{m}), 1.75-1.56(2 \mathrm{H}, \mathrm{m})$, 1.50-1.35 (2H, m), 1.29-1.10 (2H, m), 1.07 (3H, s); ${ }^{13} \mathrm{C}-\mathrm{NMR}$ $\left(\mathrm{CDCl}_{3}, 100 \mathrm{MHz}\right) \delta: 222.2,172.9,51.2,46.6,42.3,41.0$, 35.9, 30.9, 29.0, 27.7, 27.3, 22.9, 18.8; HR-MS (EI) Calcd for $\mathrm{C}_{13} \mathrm{H}_{20} \mathrm{O}_{3} m / z\left[\mathrm{M}^{+}\right]:$224.1412. Found 224.1412.

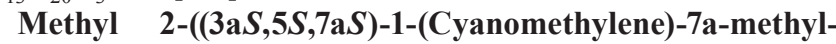
octahydro- $1 \boldsymbol{H}$-inden-5-yl)acetate To a suspension of $\mathrm{NaH}$ (26 mg, $60 \%$ oil suspension, $0.66 \mathrm{mmol})$ in DMF $(0.50 \mathrm{~mL})$ was added diethyl cyanomethylphosphonate $(0.10 \mathrm{~mL}, \mathrm{~d} 1.13$, $0.66 \mathrm{mmol})$ and stirred at $0^{\circ} \mathrm{C}$ for $1 \mathrm{~h}$ under a nitrogen atmosphere. To the solution was added compound $11(550 \mathrm{mg}$, $0.22 \mathrm{mmol})$ in anhydrous DMF $(0.51 \mathrm{~mL})$ and stirred at r.t. for $11 \mathrm{~h}$. The reaction mixture was added $\mathrm{H}_{2} \mathrm{O}$ and extracted with $\mathrm{Et}_{2} \mathrm{O}$. The combined extract was dried over $\mathrm{MgSO}_{4}$ and concentrated. The residue was purified by column chromatography $\left(\mathrm{Et}_{2} \mathrm{O}-n\right.$-hexane $\left.=1: 4\right)$ to give the desired $\alpha, \beta$-unsaturated nitrile $(50 \mathrm{mg}, 93 \%)$ as a colorless oil.

IR $\left(\mathrm{CHCl}_{3}\right) \mathrm{cm}^{-1}:$ 3018, 2954, 2927, 2216, 1730; $[\alpha]_{\mathrm{D}}^{26}+11.7$ $(c=0.29, \mathrm{EtOH}) ;{ }^{1} \mathrm{H}-\mathrm{NMR}\left(\mathrm{CDCl}_{3}, 400 \mathrm{MHz}\right) \delta: 5.10(1 \mathrm{H}, \mathrm{t}$, $J=2.4 \mathrm{~Hz}), 3.65(3 \mathrm{H}, \mathrm{s}), 2.90-2.69(1 \mathrm{H}, \mathrm{m}), 2.57-2.46(1 \mathrm{H}$, m), 2.21 (2H, d, $J=6.8 \mathrm{~Hz}), 2.07-1.15(10 \mathrm{H}, \mathrm{m}), 1.07(3 \mathrm{H}, \mathrm{s})$; ${ }^{13} \mathrm{C}-\mathrm{NMR}\left(\mathrm{CDCl}_{3}, 100 \mathrm{MHz}\right) \delta$ : 182.1, 172.9, 117.3, 89.2, 51.3, 44.9, 44.8, 41.0, 33.0, 30.9, 30.2, 28.8, 28.1, 26.0, 21.8; HR-MS (EI) Calcd for $\mathrm{C}_{15} \mathrm{H}_{21} \mathrm{NO}_{2} \mathrm{~m} / z\left[\mathrm{M}^{+}\right]$: 247.1572. Found 247.1572.

Methyl 2-((1R,3aS,5S,7aS)-1-(Cyanomethyl)-7a-methyloctahydro-1H-inden-5-yl)acetate (28) Under a hydrogen balloon atmosphere, a suspension of the $\alpha, \beta$-unsaturated nitrile $(23 \mathrm{mg}, 0.090 \mathrm{mmol}), 10 \% \mathrm{Pd} / \mathrm{C}(2.3 \mathrm{mg})$ in EtOH $(3.0 \mathrm{~mL})$ was stirred at r.t. for $2 \mathrm{~h}$. The reaction mixture was filtered through a Celite pad and concentrated. The residue was purified by column chromatography (AcOEt $-n$-hexane $=1: 5)$ to give nitrile $28(18.6 \mathrm{mg}, 80 \%, \beta: \alpha=10: 1)$ as a colorless oil.

IR $\left(\mathrm{CHCl}_{3}\right) \mathrm{cm}^{-1}: 2953,2926,1730 ;[\alpha]_{\mathrm{D}}^{26}-29.0(c=0.06$, EtOH); ${ }^{1} \mathrm{H}-\mathrm{NMR}\left(\mathrm{CDCl}_{3}, 400 \mathrm{MHz}\right) \delta: 3.67(3 \mathrm{H}, \mathrm{s}), 2.40-2.25$ $(1 \mathrm{H}, \mathrm{m}), 2.20(2 \mathrm{H}, \mathrm{d}, J=5.6 \mathrm{~Hz}), 2.17-1.03(14 \mathrm{H}, \mathrm{m}), 1.02$ $(30 / 11 \mathrm{H}, \mathrm{s}), 0.95(3 / 11, \mathrm{~s}) ;{ }^{13} \mathrm{C}-\mathrm{NMR}\left(\mathrm{CDCl}_{3}, 100 \mathrm{MHz}\right) \delta$ : 173.3, 119.8, 51.4, 47.9, 45.6, 41.6, 41.0, 31.0, 29.0, 27.9, 27.6, 26.8, 25.5, 22.6, 17.1; HR-MS (EI) Calcd for $\mathrm{C}_{15} \mathrm{H}_{23} \mathrm{NO}_{2} \mathrm{~m} / \mathrm{z}$
$\left[\mathrm{M}^{+}\right]$: 249.1729. Found 249.1727.

Methyl 2-((1R,3aS,5S,7aS)-1-(2-((E)-2,3-Bis(tert-butoxycarbonyl)guanidino)ethyl)-7a-methyloctahydro- $\boldsymbol{H}$-inden5-yl)acetate Under a hydrogen atmosphere (balloon), a suspension of nitrile $28(29 \mathrm{mg}, 0.11 \mathrm{mmol})$ and $\mathrm{PtO}_{2}$ $(3 \mathrm{mg})$ in $10 \% \mathrm{HCl}-\mathrm{MeOH}(2.7 \mathrm{~mL})$ was stirred at r.t. for $2 \mathrm{~h}$. The reaction mixture was filtered through a Celite pad and concentrated. The residue was dissolved in DMF $(1.1 \mathrm{~mL})$, and $\mathrm{Et}_{3} \mathrm{~N}(45 \mu \mathrm{L}, \mathrm{d} 0.73,0.33 \mathrm{mmol})$ and $N, N^{\prime}-$ bis(tert-butoxycarbonyl)- $1 H$-pyrazole-1-carboxamidine ( $40 \mathrm{mg}$, $0.13 \mathrm{mmol}$ ) were added. After $1 \mathrm{~h}$ stirring, the reaction mixture was added $\mathrm{H}_{2} \mathrm{O}$, extracted with $\mathrm{Et}_{2} \mathrm{O}$, and dried over $\mathrm{MgSO}_{4}$. The concentrated residue was purified by column chromatography (AcOEt- $n$-hexane $=1: 5)$ to give $N, N^{\prime}$-bisBoc guanidine $(11 \mathrm{mg}, 13 \%)$ as a colorless amorphous.

IR $\left(\mathrm{CHCl}_{3}\right) \mathrm{cm}^{-1}: 2927,1716,1635 ;[\alpha]_{\mathrm{D}}^{21}+15.0(c=0.02$, EtOH); ${ }^{1} \mathrm{H}-\mathrm{NMR}\left(\mathrm{CDCl}_{3}, 400 \mathrm{MHz}, 10: 1\right.$ diastereo mixture) $\delta$ : $11.5(1 \mathrm{H}, \mathrm{s}), 8.27(1 \mathrm{H}, \mathrm{s}), 3.66(3 \mathrm{H}, \mathrm{s}), 3.43-3.33(2 \mathrm{H}, \mathrm{m})$, $2.25(2 / 11 \mathrm{H}, \mathrm{d}, J=7.6 \mathrm{~Hz}), 2.18(20 / 11 \mathrm{H}, \mathrm{d}, J=7.2 \mathrm{~Hz}), 2.14-1.78$ $(2 \mathrm{H}, \mathrm{m}), 1.77-1.54(5 \mathrm{H}, \mathrm{m}), 1.51(9 \mathrm{H}, \mathrm{s}), 1.49$ (9H, s), 1.47-0.98 $(8 \mathrm{H}, \mathrm{m}), 0.94(30 / 11 \mathrm{H}, \mathrm{s}), 0.86(3 / 11 \mathrm{H}, \mathrm{s}) ;{ }^{13} \mathrm{C}-\mathrm{NMR}\left(\mathrm{CDCl}_{3}\right.$, $100 \mathrm{MHz}) \delta$ : 173.6, 163.6, 156.0, 153.3, 83.0, 79.2, 51.4, 49.6, 45.7, 41.8, 41.1, 40.7, 31.3, 29.3, 29.2, 28.30, 28.26, 28.1, 27.7, 27.1, 26.1, 22.7; HR-MS (FAB) Calcd for $\mathrm{C}_{26} \mathrm{H}_{46} \mathrm{~N}_{3} \mathrm{O}_{6} \mathrm{~m} / \mathrm{z}$ $\left[\mathrm{MH}^{+}\right]:$496.3386. Found 496.3390.

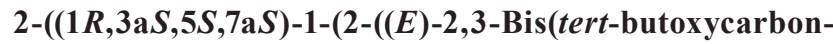
yl)guanidino)ethyl)-7a-methyloctahydro- $1 H$-inden-5-yl)acetic Acid To a solution of the $N, N^{\prime}$-bisBoc guanidine $(36 \mathrm{mg}, 0.070 \mathrm{mmol})$ in $\mathrm{MeOH}(0.70 \mathrm{~mL})$ and THF $(0.70 \mathrm{~mL})$ was added $10 \%$ aqueous $\mathrm{LiOH}(0.70 \mathrm{~mL}, 0.1 \mathrm{M})$, and the mixture was heated at r.t. for $4 \mathrm{~h}$. The reaction mixture was concentrated and neutralized with dil $\mathrm{HCl}$ on an ice bath. The mixture was extracted with $\mathrm{CH}_{2} \mathrm{Cl}_{2}$, and the combined organic layer was dried over $\mathrm{MgSO}_{4}$. The concentrated residue was purified by column chromatography (AcOEt- $n$-hexane $=1: 1$ ) to give the desired carboxylic acid $(28 \mathrm{mg}, 82 \%)$ as a white amorphous.

IR $\left(\mathrm{CHCl}_{3}\right) \mathrm{cm}^{-1}: 2981,2927,2872,1714,1633 ;{ }^{1} \mathrm{H}-\mathrm{NMR}$ $\left(\mathrm{CDCl}_{3}, 400 \mathrm{MHz}\right) \delta: 11.5(1 \mathrm{H}, \mathrm{s}), 8.27(1 \mathrm{H}, \mathrm{s}), 3.53-3.33$ $(2 \mathrm{H}, \mathrm{m}), 2.18(2 \mathrm{H}, \mathrm{d}, J=7.6 \mathrm{~Hz}), 2.14-1.54(7 \mathrm{H}, \mathrm{m}), 1.53(9 \mathrm{H}$, s), $1.49(9 \mathrm{H}, \mathrm{s}), 1.47-0.98(9 \mathrm{H}, \mathrm{m}), 0.94(3 \mathrm{H}, \mathrm{s}) ;{ }^{13} \mathrm{C}-\mathrm{NMR}$ $\left(\mathrm{CDCl}_{3}, 100 \mathrm{MHz}\right) \delta: 156.0,153.3,83.0,79.3,53.4,49.6$, 45.6, 41.1, 40.7, 31.2, 31.0, 29.1, 28.3, 28.2, 28.1, 27.7, 27.1, 26.1, 22.7; HR-MS (FAB) Calcd for $\mathrm{C}_{25} \mathrm{H}_{44} \mathrm{~N}_{3} \mathrm{O}_{6} \mathrm{~m} / z\left[\mathrm{MH}^{+}\right]$: 481.3230. Found 482.3233.

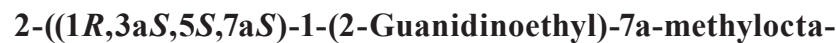
hydro-1H-inden-5-yl)acetic Acid (3d) To a solution of the carboxylic acid $(24 \mathrm{mg}, 0.050 \mathrm{mmol})$ was added $4 \mathrm{M} \mathrm{HCl}-$ AcOEt $(0.5 \mathrm{~mL})$ at $0^{\circ} \mathrm{C}$, and the mixture was stirred at r.t. for $6.5 \mathrm{~h}$. The mixture was concentrated in vacuo to give compound $3 \mathbf{d}$ (7.8 $\mathrm{mg}, 56,75 \%$ purity) as a pale yellow oil.

IR $\left(\mathrm{CHCl}_{3}\right) \mathrm{cm}^{-1}:$ 3152, 2956, 2928, 2868, 1725, 1678, 1642, 1615, 1252, 1148; $[\alpha]_{\mathrm{D}}^{20}-5.0\left(c=0.12\right.$, EtOH); ${ }^{1} \mathrm{H}-\mathrm{NMR}$ $\left(\mathrm{DMSO}-d_{6}, 300 \mathrm{MHz}\right) \delta$ : $11.95(5 \mathrm{H}$, brs $), 8.07$ (1H, brs), 7.15 (3H, brs), 3.24-2.97 (2H, m), $2.08(2 \mathrm{H}, \mathrm{d}, J=9.2 \mathrm{~Hz}), 1.08-0.97$ $(15 \mathrm{H}, \mathrm{m}), 0.92(3 \mathrm{H}, \mathrm{s}) ;{ }^{13} \mathrm{C}-\mathrm{NMR}\left(\mathrm{DMSO}-d_{6}, 100 \mathrm{MHz}\right) \delta$ : 173.7, 171.9, 156.7, 48.5, 45.4, 41.4, 30.7, 28.6, 28.4, 27.7, 26.9, 26.6, 25.6, 22.6, 21.0; HR-MS (FAB) Calcd for $\mathrm{C}_{15} \mathrm{H}_{28} \mathrm{~N}_{3} \mathrm{O}_{2} \mathrm{~m} / \mathrm{z}$ $\left[\mathrm{MH}^{+}\right]: 282.2181$. Found 282.2184.

Methyl 2-((2S,4aS,5S,8a $S)-5-H y d r o x y-4 a-m e t h y l d e c a h y-$ dronaphthalen-2-yl)acetate (29) To a solution of 19 (10 mg, 
$0.040 \mathrm{mmol})$ in $\mathrm{MeOH}(0.2 \mathrm{~mL})$ was added $\mathrm{NaBH}_{4}$ at $0^{\circ} \mathrm{C}$, and the mixture was stirred at r.t. for $5 \mathrm{~min}$. The reaction mixture was concentrated and then purified by column chromatography (AcOEt $-n$-hexane $=1: 4)$ to give compound $29(8.0 \mathrm{mg}$, $83 \%, \beta: \alpha=8.5: 1)$ as a colorless oil.

IR $\left(\mathrm{CHCl}_{3}\right) \mathrm{cm}^{-1}: 2927,2858,1730 ;[\alpha]_{\mathrm{D}}^{25}-13.0 \quad(c=0.26$, EtOH); ${ }^{1} \mathrm{H}-\mathrm{NMR}\left(\mathrm{CDCl}_{3}, 400 \mathrm{MHz}\right) \delta: 3.67(3 \mathrm{H}, \mathrm{s}), 3.23(1 \mathrm{H}$, dd, $J=12.0,4.0 \mathrm{~Hz}), 2.22(2 \mathrm{H}, \mathrm{d}, J=4.0 \mathrm{~Hz}), 2.60-0.90(15 \mathrm{H}$, m), $0.79(3 \mathrm{H}, \mathrm{s}) ;{ }^{13} \mathrm{C}-\mathrm{NMR}\left(\mathrm{CDCl}_{3}, 100 \mathrm{MHz}\right) \delta: 173.5,79.5$, 51.4, 43.5, 41.7, 38.7, 36.9, 35.2, 34.2, 30.4, 28.1, 27.8, 24.3, 9.8; HR-MS (EI) Calcd for $\mathrm{C}_{14} \mathrm{H}_{24} \mathrm{O}_{3} m / z\left[\mathrm{M}^{+}\right]$: 240.1725. Found 240.1724 .

2-((2S,4a $S, 5 S, 8 \mathrm{a} S)-5-(3-(1-(t e r t-B u t o x y c a r b o n y l) p i p e r-$ id in-4-yl)propoxy)-4a-methyldecahydronaphthalen-2yl)acetic Acid (30) To a solution of $29(22 \mathrm{mg}, 0.090 \mathrm{mmol}$, $\beta: \alpha=8.5: 1)$ in anhydrous DMF $(1.0 \mathrm{~mL})$ was added $\mathrm{NaH}$ (5.5 mg, $0.23 \mathrm{mmol}, 60 \%$ oil suspension), and the mixture was stirred at r.t. for $1 \mathrm{~h}$ under a nitrogen atmosphere. The mixture was added tert-butyl 4-(3-bromopropyl)piperidine-1carboxylate $(50 \mathrm{mg}, 0.090 \mathrm{mmol})$ and stirred for $30 \mathrm{~h}$. Then the solution was neutralized with satd aqueous $\mathrm{NH}_{4} \mathrm{Cl}$ and extracted with $\mathrm{Et}_{2} \mathrm{O}$. The extract was washed with brine and dried over $\mathrm{Na}_{2} \mathrm{SO}_{4}$. The concentrated residue was purified by column chromatography (AcOEt $-n$-hexane $=1: 3$ ) to give compound $30(12 \mathrm{mg}, 29 \%)$ as a colorless oil and $29(12 \mathrm{mg}, 53 \%)$ was recovered.

IR $\left(\mathrm{CHCl}_{3}\right) \mathrm{cm}^{-1}: 3444,2929,2358,1722,1678 ;[\alpha]_{\mathrm{D}}^{28}+3.0$ $\left(c=0.82, \mathrm{CHCl}_{3}\right) ;{ }^{1} \mathrm{H}-\mathrm{NMR}\left(\mathrm{CDCl}_{3}, 500 \mathrm{MHz}\right) \delta: 4.05(2 \mathrm{H}, \mathrm{t}$, $J=6.5 \mathrm{~Hz}), 3.23(1 \mathrm{H}, \mathrm{dd}, J=4.0 \mathrm{~Hz}), 2.68(2 \mathrm{H}, \mathrm{t}, J=12.5 \mathrm{~Hz})$, $2.20(2 \mathrm{H}, \mathrm{d}, J=6.0 \mathrm{~Hz}), 1.93-1.47(11 \mathrm{H}, \mathrm{m}), 1.45(9 \mathrm{H}, \mathrm{s})$, 1.43-0.84 (15H, m), $0.80(3 \mathrm{H}, \mathrm{s}) ;{ }^{13} \mathrm{C}-\mathrm{NMR}\left(\mathrm{CDCl}_{3}, 100 \mathrm{MHz}\right)$ $\delta: 173.1,154.9,79.5,79.2,64.3,43.7,43.5,42.0,38.7,36.9$, $35.6,35.3,34.2,32.7,32.1,30.4,28.4,28.0,27.8,25.8,24.3$, 24.0, 10.9, 9.8; HR-MS (EI) Calcd for $\mathrm{C}_{26} \mathrm{H}_{45} \mathrm{NO}_{5} \mathrm{~m} / z\left[\mathrm{M}^{+}\right]$: 451.3298. Found 451.3295.

2-((2S,4a $S, 5 S, 8 \mathrm{a} S)-4 \mathrm{a}-M e t h y l-5-(3-($ piperidin-4-yl)propoxy)decahydronaphthalen-2-yl)acetic Acid (3e) To a solution of $\mathbf{3 0}(6.2 \mathrm{mg}, 0.010 \mathrm{mmol})$ was added $4 \mathrm{M} \mathrm{HCl}-\mathrm{AcOEt}$ $(0.1 \mathrm{~mL})$ at $0^{\circ} \mathrm{C}$, and the mixture was stirred at r.t. for $5 \mathrm{~h}$. The reaction mixture was concentrated in vacuo to give compound 3e (3.6 mg, 75, 72\% purity) as a white amorphous.

IR $\left(\mathrm{CHCl}_{3}\right) \mathrm{cm}^{-1}: 3685,2928,2857,1722,1601,1453$; $[\alpha]_{\mathrm{D}}^{28}+2.4 \quad(c=0.45, \quad \mathrm{EtOH}) ;{ }^{1} \mathrm{H}-\mathrm{NMR} \quad\left(\mathrm{CD}_{3} \mathrm{OD}, 400 \mathrm{MHz}\right)$ $\delta: 4.21-4.02(2 \mathrm{H}, \mathrm{m}), 3.37(2 \mathrm{H}, \mathrm{d}, J=12.4 \mathrm{~Hz}), 3.15(1 \mathrm{H}$, $\mathrm{dd}, J=4.8,11.2 \mathrm{~Hz}), 2.96(2 \mathrm{H}, \mathrm{t}, J=12.4 \mathrm{~Hz}), 2.21(2 \mathrm{H}, \mathrm{d}$, $J=7.2 \mathrm{~Hz}), 2.12-0.90(25 \mathrm{H}, \mathrm{m}), 0.90(1 \mathrm{H}, \mathrm{s}), 0.79(2 \mathrm{H}, \mathrm{s})$; ${ }^{13} \mathrm{C}-\mathrm{NMR} \quad\left(\mathrm{CD}_{3} \mathrm{OD}, 100 \mathrm{MHz}\right) \quad \delta: 174.8, \quad 80.2, \quad 65.3,45.3$ (2C), 45.2, 42.8, 40.0, 38.4, 36.8, 35.5, 34.5, 33.4, 31.3, 30.0 (2C), 29.19, 29.16, 26.7, 25.6, 10.3; HR-MS (FAB) Calcd for $\mathrm{C}_{21} \mathrm{H}_{37} \mathrm{NO}_{3} \mathrm{~m} / z\left[\mathrm{MH}^{+}\right]: 352.2852$. Found 352.2857.

Platelet Aggregation Assay Rabbit platelet rich-plasma (PRP) was obtained from fresh rabbit blood collected into a one-tenth volume of $3.8 \%$ sodium citrate by centrifugation at $1000 \mathrm{rpm}(50 \times \boldsymbol{g})$ for $20 \mathrm{~min}$ at r.t. Platelet aggregometry followed the methods of Born ${ }^{39)}$ and O'Brien. ${ }^{40)}$ Rabbit PRP $(175 \mu \mathrm{L})$ was added to $10 \mathrm{mM} \mathrm{CaCl}_{2}(25 \mu \mathrm{L})$ and the mixture was preincubated at $37^{\circ} \mathrm{C}$ for $1 \mathrm{~min}$. The mixture was added to each sample in $0.02 \mathrm{M}$ Tris- $\mathrm{HCl}$ buffer ( $\mathrm{pH}$ 7.4) containing $0.15 \mathrm{M} \mathrm{NaCl}(25 \mu \mathrm{L})$ and incubated at $37^{\circ} \mathrm{C}$ for $5 \mathrm{~min}$. A total of $25 \mu \mathrm{L}$ of ADP (final concentration: $1-2 \mu \mathrm{M}$ ) or collagen (final concentration: $1 \mu \mathrm{g} / \mathrm{mL}$ ) was then added and incubated at $37^{\circ} \mathrm{C}$ for $5-7 \mathrm{~min}$. Platelet aggregation was measured by the turbidimetric method using HEMA TRACER 704 from MC MEDICAL Inc. (Tokyo, Japan).

Statistical Analysis Statistical analyses were performed by using Microsoft Excel 2007 software (Microsoft Co., Redmond, WA, U.S.A.). The statistical significance of differences was determined according to the student's $t$-test. $p<0.05$ was considered to be statistically significant.

Acknowledgments This work was supported by JSPS KAKENHI Grant-in-Aid for Encouragement of Young Scientists (B) 19790099. We are grateful to N. Eguchi, T. Koseki, and S. Yamada at the Analytical Center of Meiji Pharmaceutical University for performing microanalysis and mass spectrometry.

Conflict of Interest The authors declare no conflict of interest.

\section{References}

1) Badimon L., Vilahur G., Rev. Esp. Cardiol., 61, 501-513 (2008). 2) Akinosoglou K., Alexopoulos D., Thromb. Res., 133, 131-138 (2014).

3) Springer T. A., Cell, 76, 301-314 (1994).

4) Hynes R. O., Cell, 110, 673-687 (2002).

5) Xiao T., Takagi J., Coller B. S., Wang J.-H., Springer T. A., Nature (London), 432, 59-67 (2004).

6) Plow E. F., Pierschbacher M. D., Ruoslahti E., Marguerie G. A., Ginsberg M. H., Proc. Natl. Acad. Sci. U.S.A., 82, 8057-8061 (1985).

7) Gartner T. K., Bennett J. S., J. Biol. Chem., 260, 11891-11894 (1985).

8) Haverstick D. M., Cowan J. P., Yamada K. M., Santoro S. A., Blood, 66, 946-952 (1985).

9) Rose G. D., Glerasch L. M., Smith J. A., Adv. Protein Chem., 37, 1-109 (1985).

10) Kahn M., Eguchi M., "Synthesis of Peptides and Peptidomimetics, Houben-Weyl Methods of Organic Chemistry," ed. by Goodman M., Felix A., Moroder L., Toniolo C., E22c, Thieme, Stuttgart, 2004, pp. 695-740.

11) Austel V., Himmelsbach F., Müller T., Drugs Future, 19, 757-764 (1994).

12) Haubner R., Finsinger D., Kessler H., Angew. Chem. Int. Ed. Engl., 36, 1374-1389 (1997).

13) Shimaoka M., Springer T. A., Nat. Rev. Drug Discov., 2, 703-716 (2003).

14) Hanson J., de Leval X., Kolh P., Supuran C., Pirotte B., Dogné J.-M., Expert Opin. Ther. Patents, 13, 1173-1188 (2003).

15) Hartman G. D., Egbertson M. S., Halczenko W., Laswell W. L., Duggan M. E., Smith R. L., Naylor A. M., Manno P. D., Lynch R. J., Zhang G., Chang C. T.-C., Gould R. J., J. Med. Chem., 35, 4640-4642 (1992).

16) Scarborough R. M., Naughton M. A., Teng W., Rose J. W., Phillips D. R., Nannizzi L., Arfsten A., Campbell A. M., Charo I. F., J. Biol. Chem., 268, 1066-1073 (1993).

17) Hirschmann R., Sprengeler P. A., Kawasaki T., Leahy J. W., Shakespeare W. C., Smith A. B. III, J. Am. Chem. Soc., 114, 9699-9701 (1992).

18) Hirschmann R., Sprengeler P. A., Kawasaki T., Leahy J. W., Shakespeare W. C., Smith A. B. III, Tetrahedron, 49, 3665-3676 (1993).

19) Shen Y., Burgoyne D. L., J. Org. Chem., 67, 3908-3910 (2002).

20) Herzog H. L., Jevnik M. A., Tully M. E., Hershberg E. B., J. Am. Chem. Soc., 75, 4425-4427 (1953).

21) Han M., Hayes B. A., Prendergast P. T., Gupta S., J. Labelled 
Comp. Radiopharm., 43, 1149-1157 (2000).

22) Sun J., Dong Y., Cao L., Wang X., Wang S., Hu Y., J. Org. Chem., 69, 8932-8934 (2004).

23) Youn I. K., Yon G. H., Pak C. S., Tetrahedron Lett., 27, 2409-2410 (1986).

24) Shaw J. E., Knutson K. K., J. Org. Chem., 36, 1151-1152 (1971).

25) Leeds N. S., Fukushima D. K., Gallagher T. F., J. Am. Chem. Soc., 76, 2943-2948 (1954).

26) Auchus R. J., Palmer J. O., Carrell H. L., Covey D. F., Steroids, 53, 77-96 (1989).

27) Bergeron R. J., Xia M. X. B., Phanstiel O. IV, J. Org. Chem., 58, 6804-6806 (1993).

28) Li Y., Linden A., Hesse M., Helv. Chim. Acta, 86, 579-591 (2003).

29) Bernatowicz M. S., Wu Y., Matsueda G. R., Tetrahedron Lett., 34, 3389-3392 (1993).

30) Passacantilli P., Pepe S., Piancatelli G., Pigini D., Squarcia A., Tetrahedron, 60, 6453-6459 (2004).

31) Hartung W. H., J. Am. Chem. Soc., 50, 3370-3374 (1928).

32) Buchschacher P., Fürst A., Gutzwiller J., Org. Synth., 7, 368-372
(1990).

33) Kametani T., Suzuki K., Nemoto H., J. Org. Chem., 45, 2204-2207 (1980).

34) Mewshaw R. E., Taylor M. D., Smith A. B. III, J. Org. Chem., 54, 3449-3462 (1989).

35) Lajunen M., Koskinen A., J. Chem. Soc., Perkin Trans. 1, 2000, 1439-1443 (2000).

36) Leese M. P., Jourdan F. L., Gaukroger K., Mahon M. F., Newman S. P., Foster P. A., Stengel C., Regis-Lydi S., Ferrandis E., Fiore A. D., Simone G. D., Supuran C. T., Purohit A., Reed M. J., Potter B. V. L., J. Med. Chem., 51, 1295-1308 (2008).

37) Yamanaka T., Ohkubo M., Kuroda S., Nakamura H., Takahashi F., Aoki T., Mihara K., Seki J., Kato M., Bioorg. Med. Chem., 13, 4343-4352 (2005).

38) Pinciroli V., Biancardi R., Colombo N., Colombo M., Rizzo V., J. Comb. Chem., 3, 434-440 (2001).

39) Born G. V. R., Nature (London), 194, 927-929 (1962).

40) O’Brien J. R., J. Clin. Pathol., 17, 275-281 (1964). 